\title{
The Privilege Against Self-Incrimination in Bankruptcy and the Plight of the Debtor
}

\author{
Timothy R. Tarvin*
}

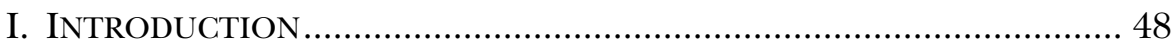

II. THE PRIVILEGE AGAINST SELF-INCRIMINATION IN BANKRUPTCY...... 56

A. The Privilege in American Jurisprudence ........................... 56

B. The Privilege in the Modern Era ....................................... 57

C. The Privilege in Varying Contexts ................................... 58

D. The Privilege in Bankruptcy Proceedings ........................... 60

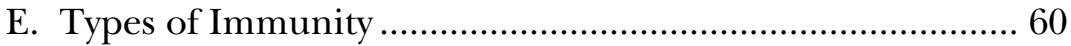

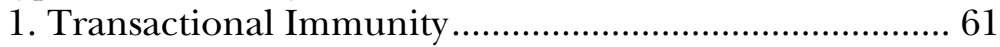

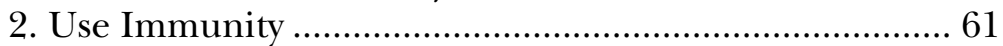

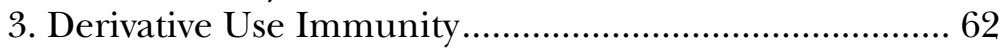

F. Two Privileges from One Right ....................................... 62

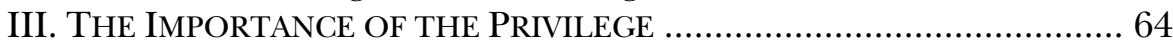

A. The Rise of the Pro Se Debtor in Bankruptcy .................... 64

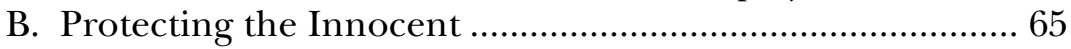

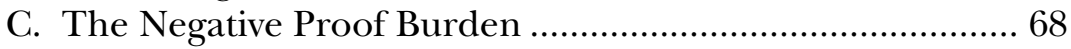

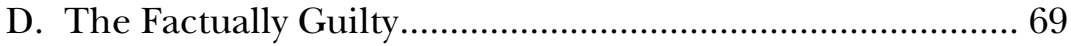

E. The Wrongfully Convicted ................................................... 69

IV. The Plight OF THE Debtor In Retaining THE PRIVILEGE .......... 70

A. Invocation of the Privilege ................................................. 70

1. Blanket Invocation is Not a "Proper Assertion" ............ 71

2. The Timing and Consequence of Asserting of the

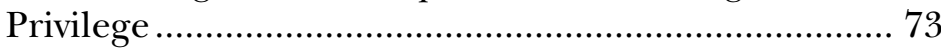

3. Invocation in the Petition and Schedules .................... 73

4. Production of Documents............................................. 74

5. Assertion of the Privilege in Oral Testimony …............ 76

B. Adverse Consequences .................................................... 77

\footnotetext{
*Associate Professor of Law, University of Arkansas School of Law. This Article was the subject of a presentation at the University of Nebraska-Lincoln School of Law. The Author recognizes the invaluable contributions of Professors Donald P. Judges, Jim Longino, Nancy B. Rapoport, and Laurent Sacharoff, and gratefully acknowledges the research and assistance of Jennifer Byrne, William M. Clark, Jr., Anna Webb Hanson and Jonathan Udoka. This Article is dedicated to my wife Christine, my parents, Roy and Jean Tarvin, and my brother, Cliff.
} 
1. Adverse Inferences ................................................... 77

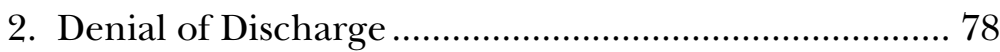

3. Inability to Testify in Other Proceedings ..................... 78

4. Contempt of Court and Imprisonment......................... 79

5. Dismissal of the Bankruptcy......................................... 79

6. Implications in Criminal Proceedings........................... 80

C. Waiver of the Privilege ...................................................... 80

1. Depositions and 2004 Examinations ............................. 82

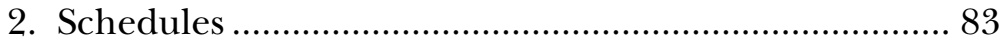

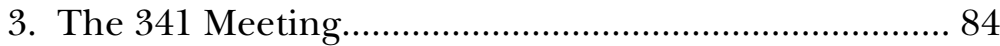

D. The Dangers of Parallel Proceedings ............................... 84

1. Protective Orders and Grand Jury Subpoenas .............. 86

2. Differences in Civil and Criminal Discovery ................ 87

3. Discovery in Bankruptcy and the Risk of Loss of the

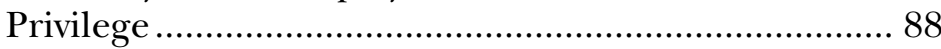

4. The Debtor's Failure to Appear, Incarceration, and the Need for Notice of the Privilege ............................. 89

E. The Compulsion of Testimony.......................................... 91

1. Procedure for the Grant of Immunity........................ 93

2. Practical Considerations................................................. 95

V. THE ForM OF REFORM TO PROTECT THE PRIVILEGE ....................... 95

A. Revision of Official Form B201A Notice to Individual

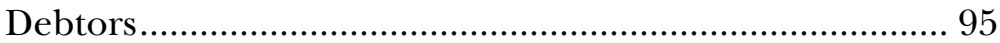

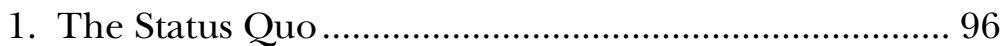

2. A Modest Proposal for Change …............................... 97

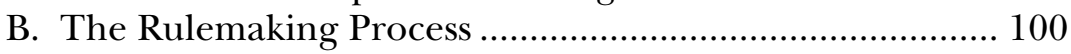

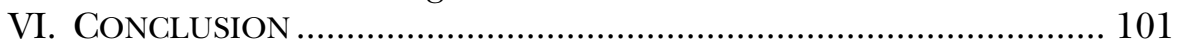

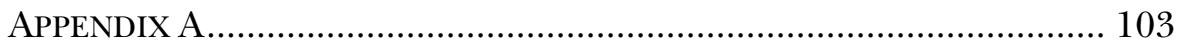

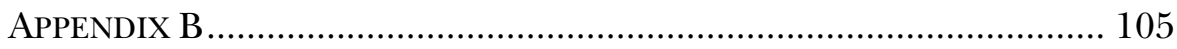

\section{INTRODUCTION}

Imagine a hypothetical situation in which a truly innocent, yet seemingly guilty, debtor, whose unwitting complicity in the delivery of testimony or documents in her bankruptcy case leads to her wrongful conviction and imprisonment in a separate criminal matter due to her ignorance of the existence of her constitutional right to the privilege and her inability to assert it effectively.

She is among the increasing number of pro se debtors in 
bankruptcy. ${ }^{1}$ She does not know she is putting herself at risk to be arrested and convicted because she, like most debtors in bankruptcy, is unaware of much of the criminal law, even though criminal law presumes that she has knowledge. ${ }^{2}$ Before examining more closely the concepts of invocation, waiver, and the consequences associated with each, consider the hypothetical plight of Sophie Debtor, a truly innocent pro se debtor whose testimony would be incriminating. ${ }^{3}$

Sophie Debtor lives in Hard Luck Town. ${ }^{4}$ She is a working mom who is separated from her husband, Hank. She lost her job and filed Chapter 7 pro se using forms on the court's website. She will appear before a trustee at a 341 meeting in thirty days to be examined under oath about her finances, including transfers to others ${ }^{5}$ and cash advances. $^{6}$ She may be asked to turn over documents. ${ }^{7}$ Sophie is

\footnotetext{
1 Joseph Callanan, Pro Se Bankruptcy Filings Growing Faster than Other Debtor Relief, LitigATION NEwS, Dec. 29, 2011, available at http://apps.americanbar.org/litigation/litigationnews/top_stories /010312-pro-se-bankruptcy-growing.html (last visited May 20, 2013) See infra Part II.A and note 79 for the amounts by which pro se filings increased. While other parties in bankruptcy such as creditors, trustees, and witnesses also enjoy the privilege, the scope of this article is limited to the individual chapter 7 debtor. Chapter 7 bankruptcies account for a majority of all bankruptcies, with over a million cases filed in the calendar year ending Sept. 30, 2011. See U.S. Bankruptcy Courts, Business and Nonbusiness Cases Commenced, by Chapter of the Bankruptcy Code, During the 12-Month Period Ending Sept. 30, 2011, http://www.uscourts.gov /uscourts/Statistics/BankruptcyStatistics/BankruptcyFilings/2011/0911_f2.pdf (last visited Aug. 16, 2013).

2 See Shevlin-Carpenter Co. v. State of Minn., 218 U.S. 57, 68 (1910).

This paper does not assess the impact the interrogation of terrorism suspects. The loss of their Miranda rights is covered by the Foreign Intelligence Surveillance Act. See 50 U.S.C. \$ 1801 et seq. (2012).

4 Song title used by the Blue-Eyed Devils, J.J. Muggler, and the Killer Dwarfs.

See 11 U.S.C. $§ 548(\mathrm{a})(1)(\mathrm{B})(\mathrm{i})$ (2012) ("The trustee may avoid any transfer ... that was made or incurred within 2 years before the date of the filing of the petition, if the debtor ... received less than a reasonably equivalent value in exchange for such transfer or ... and was insolvent on the date that such transfer was made ....").

${ }^{6}$ See 11 U.S.C. $\$ 523(\mathrm{a})(2)(\mathrm{C})(\mathrm{i})(\mathrm{I})$ (2012) ("[C] onsumer debts owed to a single creditor and aggregating more than $\$ 650$ for luxury goods ... incurred by an individual debtor on or within 90 days before the order for relief under this title are presumed to be nondischargeable.”); 11 U.S.C. § 523(a)(2)(C) (i)(II) (2012) (" $[\mathrm{C}]$ ash advances aggregating more than $\$ 925$ that are extensions of consumer credit under an open end credit plan obtained by an individual debtor on or within 70 days before the order for relief under this title, are presumed to be nondischargeable ....”); Grogan v. Garner, 498 U.S. 279, 286 (1991) (holding that the burden of proof in 523(a) cases is a preponderance of the evidence).

711 U.S.C. $\$ 542(\mathrm{e})$ (2012). But see In re Fuller, 262 U.S. 91, 93 (1923) (stating when a debtor loses control of documents, the privilege against self-incrimination does not apply).
} 
legally entitled to claim her Fifth Amendment privilege against selfincrimination. ${ }^{8}$ However, its existence was not disclosed in the forms she prepared, and she will not be told about it. She imagines she must do whatever the trustee says to get a discharge, including appearing and testifying at the meeting of creditors.

The background that gives rise to the incriminating facts is that Sophie's husband, Hank, is authorized on Sophie's credit card. While Hank was having an affair with Corrie Delecti, he gave money to Corrie from cash advances on Sophie's credit card. Hank also bought Corrie jewelry using Sophie's credit card. The transactions occurred before Sophie filed bankruptcy and without her knowledge or consent. The bill arrives after Sophie files bankruptcy so the transactions are not listed in the filing. When confronted, Hank confesses to the affair and the credit card charges. He tells Sophie that the money and jewelry are in Corrie's apartment. Then, he leaves.

Corrie Delecti is murdered and Sophie realizes that she was in Corrie's apartment building at the time of Corrie's death. Sophie had dropped by to see a friend who was not at home. Sophie's friend lives across the hall from Corrie's apartment. Corrie was the neighbor who told Sophie that her friend was out. An eyewitness saw Sophie in the hall outside Corrie's apartment near the time of the murder, but neither the police nor Sophie know this. The witness left that night and returned home to a rural area in another state away from the media coverage attendant to the murder.

The Hard Luck Town forensics team finds no evidence to link anyone specifically to the crime. Sophie has no way to establish her innocence. She has a conviction six years ago for assaulting a woman who flirted with Hank in a bar. ${ }^{9}$ She is truly innocent, but she is at risk to be indicted, tried, and wrongfully convicted because of her criminal record and her presence at the scene of the crime with the

$8 \quad 11$ U.S.C. $\$ 542$ (e) (2012) (“[S] ubject to any applicable privilege, the court may order an attorney, accountant, or other person that holds recorded information ... to turn over or disclose such recorded information to the trustee.") (emphasis added); see McCarthy v. Arndstein, 266 U.S. 34, 40 (1922) (stating that the privilege against self-incrimination applies equally to criminal and civil bankruptcy proceedings); Counselman v. Hitchcock, 142 U.S. 547, 562 (1892) (stating that the privilege against self-incrimination is not limited to criminal cases).

9 Sophie's prior conviction may or may not be admissible. See FED. R. Evid. 404 ("Evidence of a crime, wrong, or other act is not admissible to prove a person's character in order to show that on a particular occasion the person acted in accordance with the character."). 
means, motive, and opportunity. ${ }^{10}$ Additionally, unless she learns of the privilege, ${ }^{11}$ asserts it unambiguously, and insists on immunity, a court is likely to deny her discharge in bankruptcy. ${ }^{12}$

At the time of questioning, she is not a suspect in a capital crime, but she is aware that her own testimony could lead to her arrest and conviction. $^{13}$ It is ironic that although Sophie will not be told of the privilege, she will be informed of credit counseling requirements, the available chapters of the bankruptcy code, bankruptcy crimes and penalties, the availability of the papers she files for inspection by the Department of Justice (DOJ), and the risk of dismissal if she fails to file her financial information on time. ${ }^{14}$ If Sophie is not cooperative, the trustee will object to discharge and may request immunity to compel her testimony.

In sum, media reports reveal to Sophie that her responses will place her at the scene of the horrific crime with means, motive, opportunity, and no alibi. The circumstantial evidence is strong enough to arrest, indict, and possibly convict her. Sophie knows that a person unknown to her has murdered her husband's mistress only minutes after Sophie was in the hallway of the victim's apartment building to drop in on a friend who was not at home.

She does not know whether the police forensics team has been

${ }^{10}$ For purposes of indictment, prosecutors are not required to present exculpatory evidence to the grand jury and defense counsel may not be allowed to present their own evidence. See United States v. Williams, 504 U.S. 36, 52 (1992).

${ }^{11}$ At the outset the Author wishes to clarify the term privilege. The use of the term "privilege," and all related terms, pertains to the privilege against selfincrimination unless otherwise indicated.

12 For purposes of this article, "invocation" and "proper assertion" will be used interchangeably. A proper assertion is distinguishable from an ordinary assertion in that a proper assertion must be unambiguous. Berghuis v. Thompkins, 560 U.S. 370 , 386-89 (2010); see 11 U.S.C. $\$ 727(a)(12)$ (2012) (global objection to discharge related to $\S 522(\mathrm{q})(1)(\mathrm{A})$ which applies when debtor has been convicted of a felony which, under the circumstances, demonstrates that the filing of the case was an abuse of the provisions of this title); 11 U.S.C. $\$ 522$ (q)(1)(B) (iv) (2012) ("[T] he debtor owes a debt arising from any criminal act ... that caused serious physical injury or death to another individual in the preceding 5 years."); see also 18 U.S.C. $\S$ 3156(a) (3) (2012) (defining a felony as an offense punishable by a maximum term of imprisonment of greater than one year).

13 Ohio v. Reiner, 532 U.S. 17, 21 (2001) (stating that a person may assert the privilege at trial despite her claim of innocence when she has "reasonable cause to apprehend danger from her answers").

14 U.S.C. $\$ 342$ (b) (2012) (requiring clerks to furnish all debtors with Official Form B201A (notices to consumer debtors)); see also 11 U.S.C. $\$ 527$ (a) (1) (2012) (requiring debt relief agents to provide Official Form B201A to "assisted persons"). For a definition of "assisted persons," see 11 U.S.C. § 101(3) (2012) (defining an assisted person as a debtor with less than $\$ 186,825$ in non-exempt assets). 
able to find any evidence to further the investigation, or whether there are any leads. She has no prior experience or training in investigatory work; however, she is intelligent enough to know that any attempts on her part to solve the case could implicate her further. Sophie is truly innocent but at risk of being indicted, tried, and wrongfully convicted while having her bankruptcy blocked because she is unaware of her Fifth Amendment right to the privilege against self-incrimination and how to properly assert it to protect herself. $^{15}$

If she were aware of the privilege, she would invoke the privilege, because there is evidence to link her to commission of the crime. If she were represented and shared her fear of incrimination with her attorney, in all likelihood she would be advised to invoke the privilege because her responses will be incriminating. Because she is pro se, she is far more likely to respond to the questioning, despite knowledge that her responses will be incriminating.

If she were competently represented, her attorney would advise her that her failure to unambiguously invoke her privilege would result in the loss of the privilege. The plight of the debtor is that she has few choices. She must testify under oath and incriminate herself in a way that may lead to her arrest and wrongful conviction, or assert her privilege. Her only other choice would be to perjure herself. If she were represented, her attorney would advise her that, if she testifies, she must speak truthfully even if her testimony is incriminatory, and that perjury is not an option. ${ }^{16}$ Thus, she logically would not speak and unknowingly waive her privilege because she would know its importance. ${ }^{17} \quad$ Likewise, she would redact

15 See 11 U.S.C. $\$ 522(q)$ (1) (2012); 11 U.S.C. $\$ 727$ (a) (12) (2012).

16 Model Rules of Prof'L. Conduct R. 1.2(d), 3.3, 4.1, 8.4; 18 U.S.C. $\$ 1622$ (1994) (2006). But see Model Rules of Prof'L. Conduct R. 1.6 Comment (Discussion Draft 1983):

[A] disclosure adverse to the client's interest should be no greater than the lawyer reasonably believes necessary to accomplish the purpose. If . . . in . . . a judicial proceeding, the disclosure should be made in a manner that limits access to the information to the tribunal or other persons having a need to know it and appropriate protective orders or other arrangements should be sought by the lawyer to the fullest extent practicable.

17 A debtor's silence in this instance could be used against her in a subsequent criminal trial. See Salinas v. Texas, 133 S. Ct. 2174, 2181-82 (2013). Sophie's failure to say, "But I didn't kill her!" at the first meeting of the creditors is admissible unless she invokes the privilege because she cannot rely on Miranda warnings that were never given. See id. See also Michael J. Hunter, The Man on the Stairs Who Wasn't There: What Does A Defendant's Pre-Arrest Silence Have to Do with Miranda, the Fifth Amendment, 
incriminating information from any required schedules. ${ }^{18}$

The Fifth Amendment privilege against self-incrimination applies to debtors in bankruptcy. ${ }^{19}$ Despite the seeming protection of the Bankruptcy Code, ${ }^{20}$ the debtor may unwittingly waive her rights and incriminate herself by failing to invoke the privilege. ${ }^{21}$ The pro se debtor and the debtor with representation each need notice of the constitutional protection so that they are aware of the consequences of both invocation and waiver of the privilege. The possibility of a debtor's failure to properly invoke the privilege is made more probable because there is no requirement that debtors be told about the privilege prior to filing or interrogation. ${ }^{22}$

A debtor may lose the privilege based on a waiver inferred from her course of conduct or prior statements concerning a matter, ${ }^{23}$ whether or not the waiver is knowing and intelligent. ${ }^{24}$ This may be true even when counsel fails to advise the debtor to refuse to answer, ${ }^{25}$ and the debtor is unaware at the time that the statements may be incriminating. ${ }^{26}$ Once the debtor testifies, she may have waived the

or Due Process?, 28 Hamline L. REv. 277, 308 (2005); Andrew J. M. Bentz, The Original Public Meaning of the Fifth Amendment and Pre-Miranda Silence, 98 VA. L. REv. 897, 933

(2012) (arguing that an originalist view of the Fifth Amendment prohibits the substantive use of pre-Miranda silence).

${ }_{18}$ Appendix A shows a mock transcript of the first meeting of creditors and reveals the colloquy between Sophie and the trustee. Contrast Appendix A with Appendix B where Sophie (or her attorney) has been made aware of the privilege and asserts it unambiguously. See, e.g., In re Kanter, 117 F. 356, 357 (S.D.N.Y. 1902); Ensign v. Pennsylvania, 227 U.S. 592, 599 (1913); Czarlinsky v. United States, 54 F.2d 889, 893 (10th Cir. 1931), cert. denied, 285 U.S. 549 (1932); In re U.S. Hoffman Can Corp., 373 F.2d 622, 629 (3d Cir. 1967).

See, e.g., 11 U.S.C. \$ 542(e) (2006); FED. R. BANkr. 9017 (making the Federal Rules of Evidence applicable in bankruptcy including FED. R. CIV. P. 43 , 44 and 44.1); FED. R. EVID. 501 (stating that, except as required by the Constitution, federal statute, or rules of the Court, the privilege of a person is governed by the principles of the common law as interpreted by the courts of the United States in the light of reason and experience; however, in civil litigation where State law supplies the rule of decision, the privilege is determined in accordance with State law).

${ }^{20} 11$ U.S.C. $\$ 542$ (e) (2006).

21 Rogers v. United States, 340 U.S. 367, 371 (1951) (citing United States v. Murdock, 284 U.S. 141, 148 (1931), overruled on other grounds Murphy v. Waterfront Comm'n of N.Y. Harbor, 378 U.S. 52 (1983)).

${ }^{22}$ Garner v. United States, 424 U.S. 648, 654 n.9 (1976) (holding that a knowing and intelligent waiver is not required in a noncustodial setting).

${ }^{23}$ In re Litton, 74 B.R. 557, 560 (Bankr. C.D. Ill. 1987).

${ }^{24}$ In re Donald Sheldon \& Co., 193 B.R. 152, 162 (Bankr. S.D.N.Y. 1996) (citing Klein v. Harris, 667 F.2d 274, 287 (2d Cir. 1981)).

${ }_{25}$ In re A\&L Oil Co., 200 B.R. 21, 27 (Bankr. D.N.J. 1996).

26 See In re Cotillion Invs., Inc., 343 B.R. 344, 351-52 (Bankr. S.D. Fla. 2006). 
privilege for later proceedings as to all matters within the scope of her testimony. ${ }^{27}$

Without any requirement of notice, the exclusionary rule does not apply in civil proceedings. ${ }^{28}$ In short, the privilege must be invoked through its unambiguous assertion in bankruptcy, or it is lost. $^{29}$ This poses special dangers and challenges for pro se debtors, who comprise an increasing percentage of total consumer filings and who are particularly at risk because of the complexity of the proceedings and the exposure to criminal liability. ${ }^{30}$ The debtor who is represented is also placed at risk to the extent she may not be properly advised. ${ }^{31}$

To secure the just determination of every case ${ }^{32}$ and protect the debtor's privilege, the Supreme Court, under its rulemaking authority, ${ }^{33}$ should adopt a revised Official Form B201A ${ }^{34}$ for use in consumer bankruptcy cases. The revised form would provide prefiling notice in writing of the privilege against self-incrimination. To accomplish this, the Judicial Conference of the United States should promulgate the proposed form pursuant to its rulemaking authority. ${ }^{35}$ This simple change would serve to make the debtor aware of the privilege prior to filing and the consequences of invocation and waiver, so that the privilege would not be lost through ignorance, inadvertence, or lack of competent counsel. This comports with the

27 See Minnesota v. Murphy, 465 U.S. 420, 428 (1983).

28 See I.N.S. v. Lopez-Mendoza, 468 U.S. 1032, 1051 (1984).

${ }^{29}$ It is important in this context to distinguish between violations of the "privilege" and violations of the "right" against self-incrimination. The evidentiary privilege is violated when it is properly invoked, yet disclosure of incriminating information is compelled in a setting in which no criminal penalties may attach. The constitutional right against self-incrimination is violated when privileged information is unprotected whether through non-disclosure or suppression in a setting that subjects the person to the threat of imprisonment or other criminal penalties. See 21A AM. JuR. 2D Criminal Law 1036 (1965).

Filing for Bankruptcy Without an Attorney, U.S. Administrative Office of the Courts, BANKRUPTCY RESOURCES, available at http://www.uscourts.gov/FederalCourts /Bankruptcy/BankruptcyResources/FilingBankruptcyWithoutAttorney.aspx (last visited Aug. 16, 2013).

31 See supra note 9; see also In re Cotillion Invs., Inc., 343 B.R. 344 (Bankr. S.D. Fla. 2006).

32 FED. R. BANKR. P. 1001 (2012).

3328 U.S.C. $§ 2075$ (2006); U.S. CONST. Art. III, § 1

$34 \quad 11$ U.S.C. $\$ 342(\mathrm{~b}) \quad(2006)$; see Official Form B201A available at http://www.uscourts.gov/uscourts/RulesAndPolicies/rules/BK_Forms_Current/B_ 201A.pdf (providing notice of certain statutorily required information); see also infra Part IV.A.1.

35 FED. R. BANKR. P. 9009 (2012). 
federal requirement of disclosure of the privilege in other civil actions. $^{36}$ Although the existing notices in Official Form B201A are present because they are required by statutory authority to be given to the debtor, ${ }^{37}$ the Court may still act under the inherent power of its rulemaking authority to give notice of the privilege against selfincrimination. ${ }^{38}$

The debtor in bankruptcy should receive written notice of the privilege against self-incrimination and acknowledge reading it prior to filing, for only through the pre-filing delivery of notice will the debtor's right to the privilege be meaningful. This Article has four parts. Part I analyzes the scope and application of the privilege and distinguishes the privilege in bankruptcy from its counterpart in the custodial setting. Part II examines the increased risk to the pro se debtor and the value of the privilege to the factually innocent and the factually guilty who are nonetheless presumptively innocent. Part III explores the plight of the debtor under current law and explains the risk of nondisclosure of the privilege. Finally, Part IV proposes a change in the language of Official Form B201A to alleviate the

3621 U.S.C. $\$ 844$ (a) (2006), as implemented through 28 C.F.R. $\$ \S 76.4,76.6$, \& 76.9. The logical inference is that if Congress and the President through enabling legislation and administrative policy can provide notice of a constitutional privilege in a civil proceeding, the Court may do no less. For articles on the inherent rulemaking authority of courts see James R. Wolf, Inherent Rulemaking Authority of an Independent Judiciary, 56 U. Miami L. Rev. 507 (2002); A. Leo Levin \& Anthony G. Amsterdam, Legislative Control Over Judicial Rule-Making: A Problem in Constitutional Revision, 107 U. PA. L. REV. 1 (1958); Roscoe Pound, Procedure Under Rules of Court in New Jersey, 66 HaRv. L. REv. 28, 34 (1952); see also United States v. Stringer, 535 F.3d 929, 934-35 (9th Cir. 2008) (providing that SEC Form 1662 provides notice that such voluntary testimony will be provided to U.S. attorneys on a routine basis and may be used in civil or criminal proceedings); IRS Form 8300, available at http://www.irs.gov/uac

/Form-8300,-Report-of-Cash-Payments-Over-\$10,000-Received-in-a-Trade-or-Business. ("[W] e may also provide the records to appropriate state, local, and foreign criminal law enforcement and regulatory personnel in the performance of their official duties"). See, e.g., 11 U.S.C. \$ 542(e) (2006); FED. R. BANKR. 9017 (making the Federal Rules of Evidence applicable in bankruptcy including FED. R. CIV. P. 43, 44 and 44.1); FED. R. EvID. 501 (stating that, except as required by the Constitution, federal statute, or rules of the Court, the privilege of a person is governed by the principles of the common law as interpreted by the courts of the United States in the light of reason and experience; however, in civil litigation where State law supplies the rule of decision, the privilege is determined in accordance with State law).

37 U.S.C. $\$ 342$ (b) (2012).

38 United States v. Hasting, 461 U.S. 499, 505 (1983) ("[G]uided by considerations of justice," and in the exercise of supervisory powers, federal courts may, within limits, formulate procedural rules not specifically required by the Constitution or the Congress); see supra note 20. 
problems caused by nondisclosure. ${ }^{39}$

\section{The PrIVILEgE AgAinst SELF-INCRIMINATION IN BANKRUPTCY}

\section{A. The Privilege in American Jurisprudence}

The historical origin of the privilege is obscure. ${ }^{40}$ Under English case law, the privilege against self-incrimination was a common law privilege. ${ }^{41}$ As English case law developed, the privilege applied only when there appeared some possibility of incrimination as a result of being compelled to answer. ${ }^{42}$ The privilege did not apply to bankruptcy proceedings. ${ }^{43}$

The first United States Congress and three-fourths of the states constitutionalized the privilege in the Fifth Amendment as a part of the Bill of Rights in 1791. ${ }^{4}$ The Court in United States v. Burr recognized the privilege and acknowledged that the protection it afforded permitted a person to refuse to give a response to a question that could lead to incriminating evidence. ${ }^{45}$ The privilege, when properly invoked, protected the suspect, the criminal defendant, and the civil litigant from forced compulsion of incriminating evidence. ${ }^{46}$

39 See Official Form B201A, available at http://www.uscourts.gov/uscourts /RulesAndPolicies/rules/BK_Forms_Current/B_201A.pdf (providing notice of certain statutorily required information); FED. R. BANKR. P. 9009 (2012); 11 U.S.C. § 342(b) (2012).

40 The historical development of the privilege at English common law is outside the scope of this article. Some scholars link the origins of the English common law privilege to the constitutional struggles in the latter half of the seventeenth century that resulted in the abolition of the courts of Star Chamber and High Commission, while others maintain that the true origins of the common law privilege are attributable to the work of defense counsel during the rise of adversary criminal procedure at the end of the eighteenth century. See Joseph H. Langbein, The Historical Origins of the Privilege Against Self-Incrimination at Common Law, 92 MiCH. L. REV. 1047 (1994).

${ }_{41}$ McCarthy v. Arndstein, 266 U.S. 34, 41 (1924) (citing Ex Parte Cossens, 1 Buck $531,540(1820))$.

${ }^{42}$ Regina v. Boyes, 1 Best \& S. 311 (1861, Q.B.). For a discussion of the historical development of the privilege in England, see LAFAVE, ISRAEL, KinG \& KERR, Criminal Procedure $\$ 2.10$ (c) (3d ed. 2007).

43 Re Smith, 2 Deac. \& Chit. 230 (1833); McCarthy v. Arndstein, 266 U.S. 34, 41 (1924) (citing Ex Parte Cossens, 1 Buck 531, 540 (1820)).

44 U.S. CONST. amend. V.

4525 F.Cas. 38, 41 (C.C.D. Va.1807), (holding that the reach of the Fifth Amendment was so broad as to make the privilege applicable when there was a mere possibility of a criminal charge being made).

${ }^{46}$ Counselman v. Hitchcock, 142 U.S. 547, 562-63 (1892) (holding that the privilege protects a person called to testify before a grand jury, even though that person is not the accused, since grand jury is part of a "criminal case"), overruled in 
It also protected persons in criminal and civil proceedings by requiring a grant of immunity as a predicate for the surrender of the privilege. ${ }^{47}$ Although some states had bankruptcy laws, Congress did not exercise its power ${ }^{48}$ to enact a permanent bankruptcy system ${ }^{49}$ until $1898 .^{50}$

The Bankruptcy Act of July 1, 1898, or "the Act", required the debtor to testify but provided for a limited form of immunity, ${ }^{51}$ preventing the use of incriminating testimony, except in a hearing on objections to discharge. ${ }^{52}$ The immunity did not protect documents that may have been produced, ${ }^{53}$ perjury and false oaths, ${ }^{54}$ or the fruits of the debtor's testimony. ${ }^{55}$ Because the immunity provided was not coextensive with the privilege granted by Counselman $v$. Hitchcock, ${ }^{56}$ the Court held that a debtor could not be forced to give incriminating testimony. ${ }^{57}$

\section{B. The Privilege in the Modern Era}

By the early twentieth century, American case law had developed to hold that the privilege against self-incrimination applied in bankruptcy proceedings. ${ }^{58}$ Eventually, the Act was amended to

part Kastigar v. United States, 406 U.S. 441 (1972). The reasoning, or dicta, in Counselman extended the privilege to other judicial proceedings even if not part of a "criminal case."

${ }^{47}$ Counselman, 142 U.S. at 562-63.

48 U.S. CONST. art. VI, § 2; U.S. Const. art. I, § 8, cl. 4.

49 Earlier Acts lasted only briefly. See, e.g., Bankruptcy Act of 1800, ch. 19, 2 Stat. 19, repealed by Act of Dec. 19, 1803, ch. 6, 2 Stat. 248; Bankruptcy Act of 1841, ch. 9, 5 Stat. 440, repealed by Act of March. 3, 1843, ch. 82, 5 Stat. 614; Bankruptcy Act of 1867, ch. 176, 14 Stat. 517, amended by Act of June 22, 1874, ch. 390, 18 Stat. 178, repealed by Act of June 7, 1878, ch. 170, 20 Stat. 99.

${ }_{50}$ The Bankruptcy Act of July 1, 1898, c. 541, 30 Stat. 544, as amended, sometimes called the Nelson Act, repealed by Pub. L. No. 95-598.

${ }_{51}$ Id. at 11 U.S.C. $\$ 7 \mathrm{a}(10)$ (repealed 1878).

52 Ensign v. Com. of Pa., 227 U.S. 592, 599 (1913).

53 In re Fuller, 262 U.S. 91, 93-94 (1923).

54 Edelstein v. United States, 149 F. 636, 646 (8th Cir. 1906), cert. denied, 205 U.S. 543 (1907).

55 COLlier ON BANKruPtCy, § 3-344 (16th ed. 2012).

56 See 142 U.S. 547, 585-86 (1892) (reasoning that no statute that leaves the party or witness subject to prosecution after he answers the incriminating question can supplant the privilege and holding that to be valid, a statute must afford absolute immunity against future prosecution for the offense to which the question relates).

${ }^{57}$ In re Nachman, 114 F. 995,997 (D.S.C. 1902).

58 McCarthy v. Arndstein, 266 U.S. 34, 40 (1924); In re Rosser, 96 F. 305, 308 (E.D. Mo. 1899); see also Craig Peyton Gaumer \& Charles L. Nail, Jr., Truth of Consequences: The Dilemma of Asserting the Fifth Amendment Privilege Against Self-Incrimination in Bankruptcy Proceedings, 76 NEB. L. REV. 497, 501 (1997). 
provide that immunity not only applied to testimony, but to evidence "directly or indirectly derived from such testimony ...." developed a standard requiring that the privilege protect an individual when she reasonably believes a disclosure could be used in a criminal prosecution. ${ }^{60}$ The application and scope of the privilege in the various aspects of the bankruptcy process will be more closely examined in Part III. ${ }^{61}$

The debtor in bankruptcy, like persons in other civil proceedings, does not enjoy the same protections afforded by the privilege to those in criminal proceedings. ${ }^{62}$ Nevertheless, if the debtor is interrogated about matters that could prove incriminating, she may invoke the privilege against self-incrimination ${ }^{63}$ and insist on immunity before answering. ${ }^{64}$

\section{The Privilege in Varying Contexts}

The differences between the privilege in the custodial or criminal setting and the bankruptcy setting create special challenges for debtors, clearly shown by examining the procedural safeguards afforded a person in a custodial or criminal setting. ${ }^{65}$ The Court in the custodial setting seeks to ensure that any waiver of the privilege be knowing and intelligent by requiring that Miranda rights be given. $^{66}$ If the Miranda rights are not given, a presumption of

\footnotetext{
59 Pub. L. No. 91-452, 91st Cong., 2d Sess. (1970); 18 U.S.C. $§ 6002$ (2012) (codifying $\$ 207$ of the Organized Crime Control Act of 1970); see United States v. Goodwin, 470 F.2d 893 (5th Cir. 1972) (upholding conviction despite Defendant's argument that $\S 7 \mathrm{a}(10)$ prior to the amendment was unconstitutional, and holding that Congress had power to grant restricted immunity to witnesses who fail to invoke the privilege).

Ko Kastigar v. United States, 406 U.S. 441, 444-45 (1972).

61 See infra Part III.

62 See, e.g., Miranda v. Arizona, 384 U.S. 436, 444 (1966) (stating that an individual under custodial interrogation is entitled to warning (notice) of her right to remain silent or end questioning and her right to an attorney); see also Laurent Sacharoff, Miranda's Hidden Right, 63 ALA. L. REV. 535 (2012).

63 See supra note 12.

6411 U.S.C. $\$ 344$ (2006).

65 The use of the terms "custodial" and "criminal" will be used interchangeably for purposes of the Article.

See Miranda, 384 U.S. at 444 (1966) (stating that interrogation is custodial if it occurs while the individual is "in custody at the [police] station or otherwise deprived of his freedoms of action in any significant way") (emphasis added). If the interrogation is
} custodial:

[h] e must be warned prior to any questioning that he has the right to remain silent, that anything he says can be used against him in a court of law, that he has the right to the presence of an attorney, and that if 
compulsion arises that may lead to the suppression of any evidence obtained under the exclusionary rule. ${ }^{67}$

The Court has held that a person in the criminal context, who is subject to custodial interrogation, must be told of her rights against self-incrimination under the Fifth Amendment before she can waive those rights. ${ }^{68}$ The burden is on the state to establish the voluntariness of the waiver. ${ }^{69}$ Although the debtor is required to appear at various times throughout the bankruptcy process, and is subject to questioning, ${ }^{70}$ she is not entitled to Miranda warnings at any time during the proceedings. ${ }^{71}$ For this reason, the debtor may be unaware when she files her bankruptcy petition and schedules, or when she testifies at any point in the bankruptcy proceedings, that she is potentially opening herself up to criminal liability through waiver of the privilege.

\footnotetext{
he cannot afford an attorney one will be appointed for him prior to any questioning if he so desires.

${ }^{69} \quad I d$. Waiver of the privilege appears in a variety of contexts requiring the court's judgment. Compare Estelle v. Smith, 451 U.S. 454, 468 (1981) ("A criminal defendant, who neither initiates a psychiatric evaluation nor attempts to introduce any psychiatric evidence, may not be compelled to respond to a psychiatrist if his statements can be used against him at a capital sentencing proceeding."), with Noggle v. Marshall, 706 F.2d 1408, 1417 (6th Cir. 1983) (holding that the Fifth Amendment was still relevant as to a psychiatrist called by the defense but it did not warrant habeas relief).

7011 U.S.C. $\$ 341(\mathrm{~d})$ (2006) ("[T]he trustee shall orally examine the debtor ....") (emphasis added).

71 See United States v. Jackson, 836 F.2d 324, 327 (7th Cir. 1987) (holding that a debtor who was "convicted of giving false oaths at bankruptcy proceedings and concealing creditor's collateral" was not entitled to Miranda warnings during the bankruptcy proceedings). Furthermore, other courts have held that a person is not "in custody" for Miranda purposes merely because of his compelled appearance at a judicial proceeding to give testimony. See, e.g., United States v. Melendez, 228 F.3d 19, 22 (1st Cir. 2000) (hearing on motion to dismiss criminal charges of another person); United States v. Byram, 145 F.3d 405, 410 (1st Cir. 1998) (criminal trial of another); United States v. Kilgroe, 959 F.2d 802, 804-05 (9th Cir. 1992) (criminal trial of another); United States v. Vecchiarello, 569 F.2d 656, 664-65 (D.C. Cir. 1977) (depositions); Unites States v. Haldeman, 559 F.2d 31, 92 (D.C. Cir. 1976) (interrogation by the House Judiciary Committee); United States v. Pommerening, 500 F.2d 92, 99-100 (10th Cir. 1974) (grand jury witnesses); State v. Cathey, 741 P.2d 738, 743 (Kan. 1987) (inquisition hearing) overruled on other grounds by State v. Schoonover, 133 P.3d 48, 78 (Kan. 2006); State v. Tonzola, 621 A.2d 243, 247 (Vt. 1993) ("inquest" procedure to investigate crime).
} 


\section{The Privilege in Bankruptcy Proceedings}

In the early years of the republic, the Fifth Amendment right against self-incrimination was held to exist whenever there was the mere possibility of incrimination. ${ }^{72}$ The literal wording of the constitutional provision states: "No person ... shall be compelled in any criminal case to be a witness against himself...."73 Prior to Miranda, there was no obligation to advise a person in either the criminal or civil setting; the privilege, once invoked, was equally protective in both. $^{74}$

However, today the invoked privilege against self-incrimination in bankruptcy is not the equal of its custodial counterpart. ${ }^{75}$ With the passage of time, the privilege in the criminal setting has evolved into a more robust right, requiring a "knowing and intelligent" waiver. ${ }^{76}$ Miranda strengthened the presumption of compulsion on failure to warn and the application of the exclusionary rule. ${ }^{77}$ In contrast, its civil counterpart has atrophied to the point that a knowing and intelligent waiver is not required, but rather, may be inferred from prior unwarned conduct or testimony. ${ }^{78}$

\section{E. Types of Immunity}

Immunity is a term of art in the law, with many nuanced meanings dependent on context. ${ }^{79}$ The types of immunity that are relevant in this context are transactional immunity, use immunity, and derivative use immunity. Immunity acts like a dam, holding back compelled testimonial information from use in a criminal

72 United States v. Burr, 25 F. Cas. 38, 41 (C.C.D. Va. 1807).

73 U.S. CONST. amend. V (emphasis added).

${ }^{74}$ The pre-Miranda privilege was "equally protective" in the civil and criminal settings in that (1) notice was not required prior to interrogation, (2) transactional immunity was required in either context to compel testimony, and (3) no adverse inference could be drawn from silence. See Kastigar v. United States, 406 U.S. 441, 452-53 (1972). The privilege would be eroded further in 1976 when Baxter $v$. Palmiagiano allowed an adverse inference to be drawn from silence in civil cases. See 425 U.S. 308, 318 (1976).

75 Piccirillo v. New York, 400 U.S. 548, 567 (1971) (Brennan, J., dissenting).

76 Miranda v. Arizona, 384 U.S. 436, 444 (1966).

77 See id. at 462.

78 In re Donald Sheldon \& Co., 193 B.R. 152, 162 (Bankr. S.D.N.Y. 1996) (citing Klein v. Harris, 667 F.2d 274, 287 (2d Cir. 1981)); In re Litton, 74 B.R. 557, 560 (Bankr. C.D. Ill. 1987).

${ }^{79}$ Congressional immunity, sovereign immunity, diplomatic immunity, and judicial immunity are beyond the scope of this Article. Though each could touch the realm of bankruptcy practice, none lie at the heart of the Author's thesis. 
prosecution while allowing the regulated release of that same privileged information in other settings. Historically, immunity is the price the sovereign must pay for forfeiture of the privilege.

\section{Transactional Immunity}

As the term implies, transactional immunity is a grant of immunity that shields the witness from any exposure to criminal liability related to a particular transaction. ${ }^{80}$ In other words, the witness, having been given transactional immunity and compelled to testify, cannot thereafter be charged, prosecuted, convicted, or punished for any related matters despite the fact that the witness's guilt could be established without use of the witness's testimony or the fruits of that testimony. Thus, the price paid for the forfeiture of the privilege is the sovereign's guarantee that the witness is protected from exposure to criminal liability regarding the particular transaction. For that reason, the witness's constitutional right to the privilege is not violated, because the immunity removes the potential criminality and renders testimony that would otherwise be incriminating innocuous in a criminal context. ${ }^{81}$

\section{Use Immunity}

Use immunity is more limited than transactional immunity in that the witness is protected only from the "use" of the witness' testimony in any criminal proceeding against the witness. In other words, if the state has sufficient evidence apart from the testimony compelled of the witness following the grant of immunity, the witness may be tried with that evidence. The burden is on the state to establish that the evidence adduced does not use the quarantined testimony. ${ }^{82} \quad$ To the extent that use immunity rather than transactional immunity will suffice as the state's "payment" to eliminate the debtor's privilege, the value of the privilege is reduced because of the degree to which protection from criminal prosecution is lost. ${ }^{83}$

\footnotetext{
${ }^{80}$ Counselman v. Hitchcock, 142 U.S. 547, 586 (1892), overruled by Kastigar v. United States, 406 U.S. 441 (1972).

${ }^{81} I d$.

${ }^{82}$ Murphy v. Waterfront Comm'n of N.Y. Harbor, 378 U.S. 52, 103 (1964), abrogated by United States v. Balsys, 542 U.S. 666 (2007).

${ }^{83}$ Kastigar, 406 U.S. at 466-67 (Douglas, J., dissenting) ("When we allow the prosecution to offer only 'use' immunity we allow it to grant far less than it has taken away. For while the precise testimony that is compelled may not be used, leads from that testimony may be pursued and used to convict the witness.").
} 


\section{Derivative Use Immunity}

Closely related to use immunity is derivative use immunity. Derivative use immunity denies the state the use of evidence that is derived from the witness' testimony. Thus, not only is the actual testimony immune, but also the "fruits" of the immunized testimony are forbidden fruits that may not be used in a criminal proceeding against the witness. ${ }^{84}$

\section{F. Two Privileges from One Right}

Over time, the Supreme Court has altered the type of immunity necessary to compel testimony in the face of a proper assertion of the privilege. As examined below in Part III.E, the Court, over the course of history, has moved from a rule mandating transactional immunity in exchange for "immunized testimony" to a rule permitting the compulsion of privileged testimony through a grant of use immunity and derivative use immunity. ${ }^{85}$ The implications of the Court's decisions affect debtors, debtors' counsel, and the courts in dramatically different ways.

Because transactional immunity is no longer required to compel testimony over an assertion of the privilege, debtors remain at risk of prosecution after the compulsion of testimony. Instead, the Court has held that use and derivative use immunity is sufficient. ${ }^{86}$ As a result, in the words of Justice Brennan, "use immunity literally misses half the point of the privilege, for it permits the compulsion without removing the criminality." ${ }^{87}$ In short, the modern day privilege against self-incrimination in the bankruptcy setting is an anemic distant cousin of its former self.

Clearly, two distinct privileges have emerged from one

${ }^{84}$ Murphy, 378 U.S. at 79.

${ }^{85}$ While the United States Supreme Court has held that use and derivative use immunity are sufficient, some state courts still require transactional immunity. See, e.g., Pratt v. Kirkpatrick, 718 P.2d 962 (Alaska 1986); Steinberger v. District Court, In and For Tenth Judicial Dist., 596 P.2d 755 (Colo. 1979); State v. Miyasaki, 614 P.2d 915 (Haw. 1980); People ex rel. Cruz v. Fitzgerald, 363 N.E.2d 835 (Ill. 1977); In re Criminal Investigation No. 1-162, 516 A.2d 976 (Md. 1986); Matter of Pressman, 658 N.E.2d 156 (Mass. 1995); People v. McIntire, 599 N.W.2d 102 (Mich. 1999); State v. Charest, 336 N.W.2d 303 (Minn. 1983); Kelly v. Grand Jury of Lewis and Clark Cnty., 552 P.2d 1399 (Mont. 1976); People v. Chin, 490 N.E.2d 505 (1986); State ex rel. Koren v. Grogan, 629 N.E.2d 446 (Ohio 1994); State v. Bertoldi, 495 A.2d 247 (R.I. 1985); State v. Runions, 665 P.2d 1358 (Wash. 1983); State v. Cottrill, 511 S.E.2d 488 (W. Va. 1998)

${ }^{86}$ Kastigar, 406 U.S. at 462.

${ }^{87}$ Piccirillo v. New York, 400 U.S. 548, 567 (1971) (Brennan, J., dissenting). 
fundamental constitutional right. In the criminal setting, notice of the privilege must be given; waiver must be voluntary, knowing and intelligent; and no adverse inference may be drawn from an invocation of the privilege. In the civil setting, notice need not be given; waiver need not be voluntary, knowing, and intelligent; and an adverse inference may be drawn. As important as these differences are to judges, attorneys, and academics, it has the greatest impact on the civil litigant to whom no explanation is required. This is particularly true of the debtor in chapter 7 bankruptcy proceedings for at least three reasons: (1) the debtor's inability to voluntarily dismiss the proceedings ${ }^{88}$ (2) the debtor's forfeiture of ownership of books, records, and documents to the trustee as custodian of the estate $;^{89}$ and (3) the inference of waiver of the privilege that arises from the filing of statements and schedules with the petition..$^{90}$

The pro se debtor and the debtor with representation each need notice of the privilege, its scope, and its limitations no less than those who are subject to custodial interrogation. ${ }^{91}$ The constitutional protection intended for the benefit of all citizens is at risk when the existence of the privilege remains undisclosed. Without appropriate disclosures to the debtor regarding proper invocation, the possibility of inferred waiver of the privilege, and the consequences that flow from both invocation and waiver, the privilege serves no purpose.

${ }^{88}$ In re Bartee, 317 B.R. 362, 366 (B.A.P. 9th Cir. 2004) (chapter 7 suit may only be dismissed for cause). Chapter 11 debtors must also establish cause for a dismissal of their suit. 11 U.S.C. $\$ 1112$ (2012); In re Helmers, 361 B.R. 190 (Bankr. D. Kan. 2007). Chapter 12 and 13 debtors are given an absolute right to dismissal by statute, but the Eighth Circuit has held that a trustee may convert the case to chapter 7 (thereby requiring a show of cause) even after the debtor has moved for dismissal. 11 U.S.C. $\$ 1208$ (a) (2012); 11 U.S.C. § 1307(a) (2012); In re Graven, 936 F.2d 378, 387 (8th Cir. 1991); In re Molitor, 76 F.3d 218, 220 (8th Cir. 1996).

${ }^{89}$ See In re Fuller, 262 U.S. 91, 94 (1923) (holding that where the debtor is required to deliver books and papers in the bankruptcy proceedings, she is not privileged under the Fifth Amendment).

90 See Czarlinsky v. United States, 54 F.2d 889, 893 (10th Cir. 1931), cert. denied, 285 U.S. 549 (1932).

${ }_{91}$ The many scenarios under which the need for the privilege may arise are so varied that the scope of this Article cannot extend to them all. See United States v. Greer, 631 F.3d 608, 612 (2d Cir. 2011) cert. denied, 131 S. Ct. 1841 (2011) (holding that a tattoo is "testimonial" such that the privilege against self-incrimination could apply). 


\section{THE IMPORTANCE OF THE PRIVILEGE}

\section{A. The Rise of the Pro Se Debtor in Bankruptcy}

Over the last five years, the rate of pro se bankruptcy filings grew much faster than the rate of growth of overall bankruptcy filings, particularly in the western part of the United States. ${ }^{92}$ Non-pro se bankruptcy petitions rose 98 percent over the last five years, while pro se filings grew 187 percent over the same time period. ${ }^{93}$ Pro se chapter 7 (liquidation) filings jumped 208 percent, and pro se chapter 13 (reorganization) filings were up 189 percent. $^{94}$ Between 2007 and 2011, pro se chapter 7 filings increased from 6 percent to 8 percent and pro se chapter 13 filings increased from 6 percent to 10 percent. $^{95}$

To give these percentages real meaning, it is worthwhile to convert them to raw numbers. For the period ending in June 2011, there were just over one million consumer chapter 7 bankruptcies. ${ }^{96}$ The 8 percent figure represents nearly 84,000 pro se chapter 7 debtors in one year. ${ }^{97}$ Ten percent of all chapter 13 filings constituted nearly 43,000 during that same time period. ${ }^{98}$ Together, the total number of filings by pro se debtors has swollen to over 125,000 per year. ${ }^{99}$ Notably, this increase in pro se filings as a percentage of all filings occurred during a period when the total number of annual bankruptcy filings doubled. ${ }^{100}$

The effect of this dramatic increase is not spread evenly around the country. ${ }^{101}$ There appears to be some correlation between pro se filings and areas with reduced family income. ${ }^{102}$ For example, pro se

\footnotetext{
92 The Third Branch, By the Numbers-Pro Se Filers in the Bankruptcy Courts, ADMINISTRATIVE OFFICE OF THE U.S. COURTS (2011), http://www.uscourts.gov/News/TheThirdBranch/11-10-01

100 The total number of bankruptcy filings for the period ending June 2007 was 751,056 , while the total for the period ending June 2011 was 1,529,560. The Third Branch, supra note 92.

101 Id. (indicating the percent of bankruptcy cases filed pro se on a map).

102 Ronald Brownstein \& Scott Bland, The Geography of Pain, THE NAT'L J. (updated Sept.30, 2011), available at http://www.nationaljournal.com/magazine
} 
filings in the Central District of California represented 27.1 percent of all filings, ${ }^{103}$ while in the Eastern District of California pro se filings were 16.5 percent of all filings. ${ }^{104}$ In Arizona, pro se filings comprised 20.8 percent of all filings. ${ }^{105}$

\section{B. Protecting the Innocent}

The factually guilty individual, who must remain presumptively innocent, and the factually innocent person, who is only seemingly guilty, must both be protected. ${ }^{106}$ The rights of each must be guarded by the attorney-client privilege from the public disclosure of her admissions to counsel. ${ }^{107}$ Regardless of whether she is guilty or innocent, her privilege against self-incrimination must be preserved through proper invocation, if necessary. ${ }^{108}$ She must not be subjected to interrogation tactics that rob her of her right to remain silent and her right to stop the questioning. ${ }^{109}$ She must remain innocent until she decides to waive her rights and enter a voluntary plea, or demand a trial at which her peers will weigh whether the state has proven each element of any charges beyond a reasonable doubt. ${ }^{110}$

/census-sheds-new-light-on-toll-of-great-recession-20110929 (last visited Aug. 16, 2013). Twenty states saw their median family incomes plummet at least a dizzying five percent over those two years (2008-2010). The largest losses were clustered in the twin poles of Sun Belt and Rust Belt states: on the one hand, Arizona, Georgia, Florida, Nevada, Alabama, North Carolina, California, and South Carolina; on the other, Michigan, Indiana, and Ohio. Id. A more diverse list of seventeen other states lost between three and five percent of median family income. Id.

103 There were 39,478 pro se filings in the Central District of California out of a total of 145,741 consumer filings. Id.

${ }^{104}$ There were 8,877 pro se filings compared to 53,888 total consumer filings in the Eastern District of California. The Third Branch, supra note 92 (showing percentage grouping of bankruptcy cases filed pro se on a map).

105 In Arizona there were 8,625 pro se filings among the 41,377 total consumer filings. Id.

106 Coffin v. United States, 156 U.S. 432, 453 (1895) ("The principle that there is a presumption of innocence in favor of the accused is the undoubted law, axiomatic and elementary, and its enforcement lies at the foundation of the administration of our criminal law.”).

${ }^{107}$ FED. R. Evid. 501; see 1 JOHn W. STRONG ET AL., MCCORMick ON EvidEnCE 386445 (6th ed. 2006).

108 Berghuis v. Thompkins, 560 U.S. 370 (2010) (citing Davis v. United States, 512 U.S. 452, 459 (1994)) (holding that a suspect's Miranda right to remain silent, stop questioning, or request counsel must be invoked "unambiguously").

109 Miranda v. Arizona, 384 U.S. 436, 444 (1966) ("[T] he prosecution may not use statements, whether exculpatory or inculpatory, stemming from custodial interrogation of the defendant unless it demonstrates the use of procedural safeguards effective to secure the privilege against self-incrimination.”).

110 U.S. CONST. amend. VI. 
Protection of the rights of the factually guilty in a criminal situation is often the easier problem for counsel because the guilty often realize they need to exercise every legal right available to them. ${ }^{111}$ Thus, the desire for, and value of, the evidentiary privilege is clear and urgent. The guilty client may seek counsel before there is a real threat of arrest or prosecution. As the book of Proverbs says: "The wicked flee when no man pursueth: but the righteous are bold as a lion." 112 Fear is a powerful motivator, and those who believe themselves to be in violation of the law are more likely to seek to protect themselves, whether through concealment, flight, or legal counsel. On the other hand, it is equally true that the righteous or innocent are bold. They are apt to be far less cautious because they have no reason to suspect they are being pursued, making them all the more vulnerable.

And so, though it may seem ironic, the truly innocent person is on the continuum of those whose rights need protecting. ${ }^{113}$ This is true, not because of what she has done, but because of what someone else may have done. She may fall prey to the wrongdoer who would use her as a scapegoat. Law enforcement and vigilantes may target her as a suspect when the true perpetrator is not self-evident. She may be victimized by the ineptitude of investigators who overlook some clues and misdiagnose others. And, to be sure, she may naively incriminate herself because of her misplaced confidence in our system of justice and her inability to think like a criminal, a policeman, a prosecutor, a judge, or a juror. It is precisely because the innocent does not feel guilty that she is most vulnerable. Unlike her guilty counterpart, she feels no need to be guarded in her speech or conduct, nor does she sense a need for the protection afforded by counsel. In short, the system ostensibly designed for the protection of the innocent offers many opportunities for the forfeiture of her rights and liberties. ${ }^{114}$

111 This is true when the criminal conduct remains undiscovered and at all points in the criminal process.

112 Proverbs 28:1 (King James).

113 Ohio v. Reiner, 532 U.S. 17, 21 (2001) (stating that a person may assert privilege at trial of the accused despite her claim of innocence when she has "reasonable cause to apprehend danger from an answer").

114 In 2011 in United States District Courts, dismissals and acquittals totaled 8,197 in criminal proceedings. Judicial Business of the United States Courts, Administrative OfFICE OF THE UNITED STATES COURTS, available at http://www.uscourts.gov /uscourts/Statistics/JudicialBusiness/2011/JudicialBusiness2011.pdf 230 (last visited Aug. 16, 2013). In 2010 in federal criminal courts, 7,782 cases were dismissed and 415 defendants were acquitted. Dismissals and acquittals ("outcome for a defendant 
When an innocent person does assert her privilege, another danger is the cultural belief that those who assert the privilege must in fact be guilty. ${ }^{115}$ From a modern day perspective, our society may decry the injustices that gave rise to the privilege. ${ }^{116}$ Yet, in a collective denial of our own cultural hypocrisy, there is often a perception of guilt and an expectation that the accused should be compelled to speak and establish her innocence, or by her silence admit the truthfulness of the allegations, however damning. ${ }^{117}$

in a case") for the five-year period beginning in 2005 totaled 41,709. Bureau of Justice Statistics, Office of Justice Programs, Federal Criminal Case Processing Statistics, available at http://bjs.ojp.usdoj.gov/fjsrc /var.cfm?ttype $=$ one_variable\&agency $=$ AOUSC\&db_type $=$ CrimCtCases\&saf $=$ OUT (last visited Aug. 16, 2013) (Note: to access the information click the "year" tab, then the "outcome" tab to add each year for the total). One explanation for the number of dismissals and acquittals is that, while the suspect originally appeared guilty, further investigation revealed her innocence. It is logical to assume that there is a direct relationship between the loss of the privilege and the increased likelihood of arrest, prosecution, and conviction because, by definition, the suspect is compelled to provide incriminating evidence against herself. This possibility of innocence is a key reason that the debtor must be informed of her privilege against selfincrimination. This need for disclosure is manifest in the number of exonerations. Infra note 129. Therefore, if the justice system will inevitably convict the innocent, it is logical that the same system would establish innocence even when someone is factually guilty.

115 Cf. Politifact Florida, Does Rick Scott Invoking the Fifth Amendment Imply Guilt?, available at http://www.politifact.com/florida/statements/2010/oct/12

/florida-democratic-party/does-rick-scott-invoking-fifth-amendment-imply-gui/ (last visited Aug. 16, 2013) (questioning whether Florida governor Rick Scott had implied his own guilt by claiming the Fifth Amendment, as he was so accused by a television ad).

116 LaFave, Israel, King \& Kerr, Criminal Procedure $\$ 2.10$ (c) (3d ed.). The Court in Miranda noted that the privilege originated in the trial of John Lilburn who was made to take the Star Chamber Oath in 1637. The oath would have bound him to answer to all questions posed to him on any subject. He resisted the oath and declaimed the proceedings, because he believed that "no man's conscience ought to be racked by oaths imposed, to answer to questions concerning himself in matters criminal." Miranda v. Arizona, 384 U.S. 436, 458-59 (1966). On account of the Lilburn Trial, Parliament abolished the inquisitorial Court of Star Chamber. Id. The Court also illustrated the fact that custodial interrogation (even without brutality) takes a heavy toll on individuals in the following examples:

In Townsend $v$. Sain, the defendant was a 19-year-old heroin addict, described as a 'near mental defective.' The defendant in Lynumn $v$. Illinois was a woman who confessed to the arresting officer after being importuned to 'cooperate' in order to prevent her children from being taken by relief authorities. This Court, as in those cases, reversed the conviction of a defendant in Haynes $v$. Washington, whose persistent request during his interrogation was to phone his wife or attorney. Miranda, 384 U.S. at 455-56 (citations omitted).

117 Ted Sampsell-Jones, Making Defendants Speak, 93 MinN. L. REV. 1327, 1328 (2009) ("Courts should adjust the mix by rewarding defendants more for testifying 
Society's expectation that the innocent person who is accused should speak, arises from the perception that innocence is susceptible to proof. This view prevailed in the courts prior to the adoption of the privilege and is premised on the idea that only the guilty would remain silent in the face of the threat of criminal punishment. ${ }^{118}$ This perpetuates the "trilemma" of self-accusation, perjury, or contempt that the privilege was designed to avoid. ${ }^{119}$ The accused must testify, lie, or face the possibility of contempt or conviction for her silence.

\section{The Negative Proof Burden}

In a civilized society, most individuals more readily imagine being the victim of crime than the perpetrator. ${ }^{120}$ The thought of establishing legal innocence may not seem frightening. Instead, a person may presume that our judicial system will protect her, ${ }^{121}$ as the law goes to great lengths to avoid asking a litigant to prove a negative proposition precisely because of the admitted difficulty. ${ }^{122}$ Statutes of limitation and statutes of fraud are examples of society's desire to avoid injustice to defendants in civil and criminal proceedings due to concerns about insufficiency of evidence. ${ }^{123}$

The law and society acknowledge that proving a negative

and punishing them more for declining to testify.").

118 LaFave, Israel, King \& Kerr, Criminal Procedure $\$ 2.10$ (c) (3d ed.).

119 Pennsylvania v. Muniz, 496 U.S. 582, 596 (1990) ("At its core, the privilege reflects our fierce "unwillingness to subject those suspected of crime to the cruel trilemma of self-accusation, perjury or contempt." (quoting Doe v. United States, 487 U.S. 201, 212 (1988))).

${ }^{120}$ In this context, a civilized society is one governed by the rule of law and in which most people are law-abiding.

${ }^{121}$ In a recent study, seventy-two participants (first year Psychology students) were deemed "guilty or innocent of a mock theft [and] were apprehended for investigation. Motivated to avoid prosecution and trial, they were confronted by a neutral, sympathetic, or hostile male 'detective' who sought a waiver of their Miranda rights.” Saul M. Kassin \& Rebecca J. Norwick, Why People Waive Their Miranda Rights: The Power of Innocence, 28 LAW AND Human BEHAVIOR 211 (2004). "[P] articipants who were truly innocent were significantly more likely to sign a waiver than those who were guilty." Id. The study concluded that most subjects waived their rights even in a hostile detective condition where the risk of interrogation was apparent based on a naive belief in the power of their innocence to set them free. Id. at 212-13.

122 The burden of proof is on the civil litigant seeking redress to adduce the necessary evidence and affirmatively prove the elements of the cause of action or the elements of the crime in a criminal action. Sadeghi v. INS, 40 F.3d 1139, 1143 (10th Cir. 1994); Rockwell v. Comm'r, 512 F.2d 882, 887 (9th Cir. 1975); People v. Orth, 530 N.E.2d 210, 215 (Ill. 1988); Lublin v. Cent. Islip Psychiatric Ctr., 372 N.E.2d 307, 310 (N.Y. 1977); Elkins v. United States, 364 U.S. 206, 218 (1960).

${ }_{123} 51$ AM. Jur. 2D, Limitation of Actions $\$ 9$ (2007); 73 AM. Jur. 2D, Statute of Frauds $\S 425$ (2007). 
proposition, such as true innocence, may require much more evidence than proving an affirmative proposition, such as guilt. ${ }^{124}$ The danger is the possibility that the accused is truly innocent, coupled with the magnitude of the harm arising from a wrongful conviction. ${ }^{125}$ The privilege protects the truly innocent person whose testimony would make her appear guilty. ${ }^{126}$

\section{The Factually Guilty}

The value of the privilege is no less important to the debtor who is factually guilty than it is to the debtor who is only seemingly guilty. The privilege protects the factually guilty person by preserving the presumption of innocence and the right to a fair trial. ${ }^{127}$ The presumption of innocence is critical to providing fundamental fairness to the accused in a criminal setting. It is diminished to the extent that the accused is compelled to testify through the inadvertent loss of the privilege. Because guilt is a legal conclusion that must await the outcome of judicial proceedings, preservation of the privilege is essential to protect the factually guilty. The American legal system is founded on an accusatorial basis, not inquisitorial. ${ }^{128}$

\section{E. The Wrongfully Convicted}

The risk of wrongful arrest, prosecution, and conviction is real. With modern day forensics, the number of innocent people who have been wrongfully convicted is increasingly evident. As of August 19, 2013, the Innocence Project has exonerated 311 persons through

124 See Elkins, 364 U.S. at 218.

125 Consider Eddie Joe Lloyd, a mentally handicapped man who falsely confessed to the rape and murder of a young woman after police led him to believe that he would smoke out the real killer. See Barry Scheck \& Peter Neufeld, 250 ExoneratedToo Many Wrongfully Convicted, Innocence Project Report, available at http://www.innocenceproject.org/docs/InnocenceProject_250.pdf (last visited Aug. 16, 2013). See discussion supra at Part II.E. See also Justin Brooks, Wrongful CONVICTIONS 4 (1st ed. 2011).

${ }^{126}$ Ohio v. Reiner, 532 U.S. 17, 21 (2001) (stating that a person may assert privilege at trial of the accused despite her claim of innocence when she has "reasonable cause to apprehend danger from an answer").

127 United States v. Impson, 531 F.2d 274, 277 (5th Cir. 1976) ("Silence is the right of the innocent as well as of the guilty."); De Luna v. United States, 308 F.2d 140, 151 (5th Cir. 1962) ("To make the privilege against self-incrimination effective and to preserve the presumption of innocence, almost all of the states adopted laws forbidding comment on a defendant's neglect or refusal to testify and decreeing that no inference should be drawn from his silence.").

128 Rogers v. Richmond, 365 U.S. 534, 541 (1961). 
DNA testing in the United States. ${ }^{129}$ The protection of the innocent is inextricably linked to the presumption of innocence and the privilege against self-incrimination. False confessions and incriminating statements lead to wrongful conviction in approximately 27 percent of cases. ${ }^{130}$ Nearly 10 percent of exonerees pled guilty to crimes they did not commit. ${ }^{131}$

Wrongful convictions are more likely to occur when an adverse inference is drawn from exercise of the privilege, causing an innocent person to appear guilty. Although jurors may be instructed not to consider a defendant's refusal to testify, in reality, it is difficult for a jury instruction to override the temptation to believe that the defendant has something to hide. ${ }^{132}$

\section{The Plight of the Debtor In Retaining the PRIVILEge}

The privilege may be lost at any time. To the extent that the debtor is not aware that the privilege may be waived, or how it may be waived, the privilege is at risk. Thus, even a debtor that is aware of the privilege may inadvertently waive it. When facing criminal charges, retaining the privilege is as critical as claiming it.

\section{A. Invocation of the Privilege}

During the course of the bankruptcy proceedings, a debtor may be exposed to various instances in which she may be asked to provide incriminating evidence and need to invoke the privilege. The Code requires the debtor to attend a meeting of creditors and be orally examined under oath by a trustee. ${ }^{133}$ The debtor must answer

129 The InNOCENCE PrOJECT, http:/ / www.innocenceproject.org/ (last visited Aug. 19, 2013). The Innocence Project details each one of the first 250 DNA exoneration cases and includes statistics on common causes of the wrongful convictions. See Barry Scheck \& Peter Neufeld, 250 Exonerated-Too Many Wrongfully Convicted, Innocence Project Report, 1, 51 (2010), available at http://www.innocenceproject.org/docs /InnocenceProject_250.pdf (last visited Aug. 16, 2013).

${ }^{130} \quad I d$. at $32-33$.

131 Id.

132 In 1980, one study concluded that defendants who appeared to withhold evidence were judged more harshly, indicating that something (we don't know what) goes on in the mind of the jury. E. GIL Clary \& DAVID R. SHAFFER, Effects of Evidence Withholding and a Defendant's Prior Record on Juridic Decisions, 112 J. Soc. Psychol. 237 (1980). Another study concluded, however, that pleading the fifth did not have as great an effect on the strength of the conviction meted out by mock jurors as did pleading guilty. Shelley M. Fischer \& LaWrence A. FeHr, The Effect Of Defendant's Plea On Mock Juror Decisions, 125 J. SOc. PsYCHOL. 531, 531-33 (1985).

133 U.S.C. $\$ 344$ (2006) ("Immunity for persons required to submit to examination, to testify, or to provide information in a case under this title may be 
questions of creditors at that meeting. The debtor may also be deposed in a 2004 examination. ${ }^{134}$ Each of these proceedings is recorded and the examining party has the right to have the examination reduced to writing.

The Bankruptcy Code anticipates the dilemma of the debtor who is asked to provide incriminating testimony under oath. ${ }^{136}$ The Code provides that a debtor may be granted immunity regarding incriminating testimony prior to giving the testimony. ${ }^{137}$ If the debtor is granted immunity and persists in refusing to answer questions, the debtor may be denied a discharge. ${ }^{138}$ If the debtor is not granted immunity, she may refuse to testify based on a proper assertion of her privilege against self-incrimination. ${ }^{139}$

Although the Code does not specifically define the type or scope of immunity required to compel the debtor to testify, the Court has held that the combination of use and derivative use immunity is sufficient. ${ }^{140}$ Transactional immunity is not required. ${ }^{141}$

Given the complex decisions that a debtor faces, she needs assistance of counsel to avoid the pitfalls. Counsel's explanation of the debtor's rights and responsibilities at each juncture protects the debtor against the inadvertent loss of the privilege.

\section{Blanket Invocation is Not a "Proper Assertion"}

Though the debtor may wish to properly assert her privilege against self-incrimination, certain requirements must be met for an assertion to be proper. The privilege may be properly asserted if there is (1) compelled disclosure that is (2) found to be testimonial

granted....")

${ }^{134}$ FED. R. BANKr. P. 2004 (2012). A 2004 examination is an examination that occurs only upon motion of a party in interest as opposed to the 341 meeting which is mandatory. A court reporter may be present during the 2004 examination.

135 In re Jackson, 13 F. Cas. 204, 205 (E.D.N.C. 1874).

136 See 11 U.S.C. $\$ 542$ (e) (2006) (stating that subject to any applicable privilege, the debtor must turn over financial documents).

13711 U.S.C. $\$ 344$ (2006).

138 See 11 U.S.C. $\$ 727$ (a) (6) (B) (2012) ("[T] he court shall grant the debtor a discharge, unless the debtor has refused, in the case on the ground of privilege against self-incrimination, to ... testify, after the debtor has been granted immunity with respect to the matter concerning which such privilege was invoked.").

139 In re Gi Yeong Nam, 245 B.R. 216, 224 (Bankr. E.D. Pa. 2000); In re Potter, 88 B.R. 843 (Bankr. N.D. Ill. 1988).

Kastigar v. United States, 406 U.S. 441, 452 (1972).

${ }^{141} I d$. 
and (3) incriminatory. ${ }^{142}$ A debtor may not use a blanket invocation of the privilege to refuse to answer all questions in a proceeding. ${ }^{143}$ Instead, a debtor must be ready to show, related to each question, that there is a real danger of incrimination, ${ }^{144}$ that there is some nexus of risk, ${ }^{145}$ or that the information provided will provide a link in the chain of information required for prosecution. ${ }^{146}$ Furthermore, the debtor must show that the fear of prosecution is more than fanciful. ${ }^{147}$

The Supreme Court has recognized that these requirements for invoking privilege create a paradox in that, if a witness is required to prove the hazard of prosecution, she would be compelled to surrender the very information and protection that the privilege against self-incrimination is designed to protect. ${ }^{148}$ To avoid this result, some courts have required the debtor to explain the incriminatory nature of specific questions under oath, in camera, or by affidavit. ${ }^{149}$ The debtor may not use the privilege as a basis to refuse to attend the section 341 meeting of creditors $^{150}$ or to refuse to

142 In re Connelly, 59 B.R. 421, 430-31 (Bankr. N.D. Ill. 1986).

${ }_{143}$ Id. at 430; accord In re Brandenberg, No. 06-30709, 2007 WL 117391 (Bankr. E.D. Tenn. Jan 10, 2007); see also In re ICS Cybertronics, Inc., 107 B.R. 821, 829 (Bankr. N.D.N.Y. 1989) (holding that a former officer of a corporation was not entitled to issue a blanket refusal to testify at an examination under FED. R. BANKR. P. 2004, but was ordered to answer each question propounded to him unless he proffered particularized responses to each, explaining some nexus between the risk of criminal prosecution and the information requested).

144 In re Morganroth, 718 F.2d 161, 167 (6th Cir. 1983); In re Mudd, 95 B.R. 426, 427 (Bankr. D. Tex. 1989).

${ }_{145}$ Martin-Trigona v. Gouletas, 634 F.2d 354, 360 (7th Cir. 1980).

146 In re French, 127 B.R. 434, 440 (Bankr. D. Minn. 1991) (holding that a Chapter 11 debtor, charged with a felony, may assert her Fifth Amendment privilege against self-incrimination at the first meeting of creditors without losing her right to discharge if the debtor is not offered immunity, but must do so as to each question posed, and that where the questions would potentially furnish a link in the chain of evidence needed to prosecute, no further inquiry is needed).

${ }_{147}$ In re Mart, 90 B.R. 547, 550 (Bankr. S.D. Fla. 1988) (permitting a discharge where the debtor was potentially involved in her husband's alleged criminal conduct and invoked her Fifth Amendment privilege against self-incrimination, because the fear of prosecution was more than fanciful); see also In re Johnson, 387 B.R. 728 (S.D. Ohio 2008) (denying the debtor a discharge where the debtor purported to "plead the Fifth" in refusing to answer questions at the first meeting of creditors, but where there was no fear of prosecution; rather, the debtor was blatantly trying to avoid cooperation with the Trustee).

${ }_{148}$ See Hoffman v. United States, 341 U.S. 479, 486-87 (1951).

149 In re Connelly, 59 B.R. 421, 445, 447-48 (Bankr. N.D. Ill. 1986)

In In $r e$ Russell, 392, B.R. 315, 368 (Bankr. E.D. Tenn. 2008). 
provide the required schedules and statement of financial affairs. ${ }^{151}$

2. The Timing and Consequence of Asserting of the Privilege

A debtor may make a proper assertion of her right against selfincrimination throughout the bankruptcy process. ${ }^{152}$ She may invoke her right in the completion of the bankruptcy schedules, during oral testimony, and responding to requests for production of documents.

However, while the debtor may avoid exposing herself to incrimination through her direct testimony, she may be subject to other consequences. Among other things, adverse inferences may be drawn in the bankruptcy proceedings, adversary proceedings, Rule 2004 examinations, ${ }^{153}$ and criminal proceedings. ${ }^{154}$

\section{Invocation in the Petition and Schedules}

The Code requires that a debtor file a list of creditors, a schedule of assets and liabilities, a schedule of current income and current expenses, a statement of the debtor's financial affairs, and other schedules. ${ }^{155}$ The Code gives the court discretion to allow a

$151 \quad$ Id at 361

152 See Berghuis v. Thompkins, 560 U.S. 370, 371 (2010) (stating that a suspect's Miranda right to remain silent, stop questioning, or request counsel must be invoked "unambiguously") (quoting Davis v. United States, 512 U.S. 452, 459 (1994)). It must be reasoned that a civil litigant in a non-custodial context, including the debtor, would not be allowed to invoke the privilege more easily, and thus the best practice is to invoke the privilege through an assertion that is unambiguous.

153 Federal Savings \& Loan Ins. Corp. v. Sutherlin 109 B.R. 700, 706 (Bankr. E.D. La. 1989) (holding that the Receiver of an insolvent bank was entitled to rely upon and draw a negative inference from Debtor's invocation of his 5 th Amendment rights during a 2004 examination in motion to dismiss case); In re Grand Jury Subpoena, 836 F.2d 1468, 1476 (4th Cir. 1988) ("[T] he trier of fact may also use the silence of a deponent for relevant inference that it creates.”); Chase Manhattan Bank, N.A., v. Frenville, 67 B.R. 858, 862 (Bankr. D. N.J. 1986) (using adverse inferences to deny dischargability to certain debts where the debtor asserted the Fifth Amendment in response to questions regarding their dischargability); In re Hanson, 225 B.R. 366, 371 (Bankr. W.D. Mich. 1986) (holding that a debtor who invoked the Fifth Amendment privilege throughout the discovery process for an adversarial proceeding was not allowed to waive the privilege on the day of trial and testify because of unfair prejudice and surprise).

154 Czarlinsky v. United States, 54 F.2d 889, 893 (10th Cir. 1931), cert. denied, 285 U.S. 549 (1932) ("It is our opinion that defendant, by filing the schedules in bankruptcy without objection, waived his privilege as to any use to which such schedules would be put, including evidence in a criminal prosecution."); see infra Part III.B.1.

15511 U.S.C. $\$ 521$ (2012); FED. R. BANKR. P. 1007, 1009, 4002, \& 9011. 
debtor to omit certain information. ${ }^{156}$ Historically, courts have allowed the debtor to refrain from turning over incriminating schedules. ${ }^{157}$ Courts have held that debtors must complete schedules when there is clearly no direct and apparent self-incrimination that necessarily attaches to the information required by the schedules. ${ }^{158}$ However, if the court finds that the debtor's refusal to provide information required by the Code is justified under the Fifth Amendment right against self-incrimination, it may excuse compliance with the requirement. ${ }^{159}$

\section{Production of Documents}

At various times throughout the bankruptcy proceedings, the debtor may be asked to produce documents related to the bankruptcy estate, which is created by the filing of the petition. ${ }^{160}$ Examples of such documents include bank statements, tax returns, deeds, and titles. As in other types of civil cases, the Supreme Court has held that the incriminating contents of documents in the debtor's possession are not privileged because there has been no compulsion to create the documents, and the documents were created voluntarily prior to the request for turnover. ${ }^{161}$ However, the Court has found that the act of producing documents itself may be sufficiently testimonial to warrant Fifth Amendment protection, even though information in certain documents may contain incriminating information. ${ }^{162}$ For instance, by producing the documents, the debtor may be making admissions that (1) the documents exist, (2)

156 See 11 U.S.C. $\$ 521$ (a) (1) (2006) (“[T] he debtor shall file a list of creditors; and unless the court orders otherwise, [other schedules].") (emphasis added).

157 See, e.g., In re Kanter, 117 F. 356, 357 (S.D.N.Y. 1902); In re U.S. Hoffman Can Corp., 373 F.2d 622, 629 (3d Cir. 1967).

158 See, e.g., In re Arend, 286 F. 516, 517-18 (2d Cir. 1922); Padolin v. Lesher Warner Dry Goods Co., 210 F. 97, 102-04 (3d Cir. 1914).

${ }^{159}$ In re U.S. Hoffman Can Corp., 373 F.2d 622, 626-27 (3d Cir. 1967); In re Connelly, 59 B.R. 421, 447-48 (Bankr. N.D. Ill. 1986); In re Kaufman, 35 B.R. 26, 28 (Bankr. D. Haw. 1983).

${ }^{160} 11$ U.S.C. $\$ 541$ (a) (2012). The commencement of a case creates an estate comprised of all legal and equitable interests of the debtor in property as of the commencement of the estate wherever located and by whomever held except as provided by $\S 541$ (b) and (c) (2). The trustee is the representative of the estate. See 11 U.S.C. § 323(a) (2012). Pursuant to 11 U.S.C. § 521(a) (4) "[T] he debtor shall ... surrender to the trustee all property of the estate and any recorded information, including books, documents, records, and papers, relating to property of the estate, whether or not immunity is granted under section 344 of this title . ..." (emphasis added).

161 Fisher v. United States, 425 U.S. 391, 410 n.11 (1976).

162 United States v. Doe, 465 U.S. 605, 617 (1984); Fisher, 425 U.S. at 410 (1976). 
that the documents are in the possession and control of the debtor, or (3) that the debtor believes that the documents she produces are the documents that were requested, thereby authenticating the documents. $^{163}$ In such a case, a grant of use and derivative use immunity is required in order to compel the testimony sought. ${ }^{164}$

The first step in determining whether a debtor may invoke her privilege against self-incrimination and thus refuse to produce documents is to determine whether the documents are property of the debtor's estate. ${ }^{165}$ The privilege against self-incrimination only applies to property in which the debtor holds title. ${ }^{166}$ If the title to the documents is vested in the bankruptcy estate or another third party, the debtor may not be able to invoke her privilege to suppress the documents. ${ }^{167}$ If the requested documents are property of the bankruptcy estate, courts have found that the turnover of those assets is not testimonial and is therefore not in conflict with the privilege against self-incrimination. ${ }^{168}$

Courts disagree on the proper test for deciding whether requested documents are property of the debtor's estate for the purpose of asserting the privilege. One view is that possession alone is a sufficient basis for assertion of the privilege. The Ninth Circuit

163 In re Connelly, 59 B.R. 421, 440 (Bankr. N.D. Ill. 1986).

164 Doe, 465 U.S. at 617 (1984); see discussion infra note 171.

165 See 11 U.S.C. $\$ 541$ (a) (2006) (defining property of the estate). Property claimed as exempt is property of the estate until the court allows the exemption or the time for objections to exemptions has lapsed. In re Bucchino, 439 B.R. 761, 77071 (Bankr. D. N.M. 2010); In re Campbell, 313 B.R. 313, 320-21 (B.A.P. 10th Cir. 2004); In re Calvin, 329 B.R. 589, 601-02 (Bankr. S.D. Tex. 2005); Wells Fargo Bank, N.A. v. Jimenez, 406 B.R. 935, 940-45 (D. N.M. 2008), vacated, 7-05-15473 MA, 2009 U.S. Dist. LEXIS 108903 (Bankr. D. N.M. Apr. 7, 2009). For the duration that documents are property of the estate, the trustee would potentially be able to examine (and even photocopy) anything incriminating. In those jurisdictions that require the debtor to have ownership and possession to assert the privilege (see infra notes 169 and 171), the debtor would not technically be able to assert the privilege in this time period. See 11 U.S.C. $\$ 522$ (1) (2006) and FED. R. BANkr. P. 4003(b) (1) for requirement to file claim of exemptions and procedure for objections.

${ }_{166}$ Dier v. Banton, 262 U.S. 147, 149-50 (1923); Ex parte Fuller, 262 U.S. 92, 9394 (1923)

16711 U.S.C. \$ 521 (a) (4) (2006); United States v. Falley, 489 F.2d 33, 41 (2d Cir. 1973); United States v. Egenberg, 443 F.2d 512, 517-18 (3d Cir. 1971); see also In re Lufkin, 255 B.R. 204, 210 (Bankr. E.D. Tenn. 2000) (holding that a Debtor-Attorney could not assert the Fifth Amendment right against self-incrimination to prevent a receiver, who had been appointed to take possession of law firm prior to involuntary bankruptcy, from disclosing documents to a Trustee).

${ }_{168}$ See In re Krisle, 54 B.R. 330, 340-41 (Bankr. D. S.D. 1985); In re Deveraux, 48 B.R. 644, 646 (Bankr. S.D. Cal. 1985); In re Crabtree, 39 B.R. 726, 732 (Bankr. E.D. Tenn. 1984); In re Kaufman, 35 B.R. 26, 27-28 (Bankr. D. Haw. 1983). 
has held that possession of the documents by the debtor may be a necessary and sufficient condition to invoke the privilege. ${ }^{169}$ That court reasoned that even if the debtor did not own the requested documents, there is the same potential for incrimination based on identification, possession, and authentication. ${ }^{170}$ If however, the documents are not property of the estate and the debtor is in possession of the documents, then the debtor must show that the act of producing the documents is sufficiently testimonial to warrant Fifth Amendment protection. ${ }^{171}$

The other view is that ownership and possession are necessary. For instance, the Second Circuit has held that ownership of documents is essential to suppress them on Fifth Amendment grounds. ${ }^{172}$ In order to rightfully assert her privilege against self-incrimination, a debtor must show ownership and possession of the requested documents, and she must show that they are self-incriminatory. ${ }^{173}$

\section{Assertion of the Privilege in Oral Testimony}

During bankruptcy proceedings, the debtor is expected to give oral testimony at the meeting of creditors and may be asked to testify at 2004 exams or certain hearings. ${ }^{174}$ Pursuant to 11 U.S.C. $§ 344$, the debtor may be granted immunity regarding her oral testimony under Part V of Title 18 of the United States Code for the purposes of this examination. ${ }^{175}$ Neither the Criminal Code nor the Bankruptcy Code specifies the type of immunity to be granted, but the Court has held that a grant of use and derivative use immunity is sufficient to compel the debtor to testify under oath. ${ }^{176}$

If the debtor is not offered immunity, the debtor may refuse to testify under the privilege and still retain her right to a discharge. ${ }^{177}$ The use of the privilege in chapter 7 consumer cases is well

169 United States v. Cohen, 388 F.2d 464, 468 (9th Cir. 1967).

I70.

171 In re Ross, 156 B.R. 272, 275-77 (Bankr. D. Idaho 1993).

172 Falley, 489 F.2d at 41.

173 Id.

17411 U.S.C. $\$ 341$ (2006); FED. R. BANKR. P. 2004.

175 U.S.C. $\$ 344$ (2006).

176 Kastigar v. United States, 406 U.S. 441, 453 (1972).

17711 U.S.C. $\$ 727$ (a)(6)(A) (2006); In re Minton Grp, Inc., 43 B.R. 705, 709 (Bankr. S.D.N.Y. 1984); In re Salzman, 61 B.R. 878, 889 (Bankr. S.D.N.Y. 1986); In re Connelly, 59 B.R. 421, 426 (Bankr. N.D. Ill. 1986); In re Hulon, 92 B.R. 670, 673 (Bankr. N.D. Tex. 1988) 
documented. ${ }^{178}$ However, assertion of the privilege in a chapter 13 proceeding is problematic because of the requirement that the debtor's plan be submitted in good faith. ${ }^{179}$ Unless immunity is granted, the privilege may be invoked to avoid incriminating questions or offering other incriminating information considered testimonial whether during discovery or trial. ${ }^{180}$ The debtor may invoke the privilege in bankruptcy to justify a refusal to provide information otherwise relevant to the administration of the estate. ${ }^{181}$

\section{B. Adverse Consequences}

\section{Adverse Inferences}

Though the debtor may properly assert her privilege to avoid revealing incriminatory evidence, she may face adverse consequences. When a debtor invokes her Fifth Amendment privilege against selfincrimination in civil proceedings, adverse inferences may be drawn from the invocation ${ }^{182}$ by receivers, Trustees, and the Court. ${ }^{183}$ In some situations, such inferences may lead to certain debts being deemed nondischargeable. ${ }^{184}$

178 Turner, 43 B.R. at 709 .

17911 U.S.C. $\$ 1325$ (a) (3) (2006); In re Girdaukas, 92 B.R. 373, 376 (Bankr. E.D. Wis. 1988) (supporting the use of the Fifth Amendment in Chapter 7, but noting that it may be difficult for a debtor to establish a good faith plan under Chapter 13 while using the Fifth Amendment privilege).

180 Grand Jury Proceedings (Williams) v. United States, 995 F.2d 1013, 1018 n.11 (11th Cir. 1993).

181 In re Hyde, 235 B.R. 539, 542 n.1 (S.D.N.Y. 1999), aff'd, 205 F.3d 1323 (2d Cir. 2000).

${ }^{182}$ See In re Brandenberg, No. 06-30709, 2007 WL 117391 (Bankr. E.D. Tenn. Jan. $10,2007)$.

183 See In re Grand Jury Subpoena, 836 F.2d 1468, 1476 (4th Cir. 1988) (“[T]he trier of fact may also use the silence of a deponent for relevant inferences that it creates"); Fed. Sav. \& Loan Ins. Corp. v. Sutherlin, 109 B.R. 700, 706 (E.D. La. 1989) (stating that a receiver was entitled to draw a negative inference from the debtor's invocation of his Fifth Amendment rights during a Rule 2004 examination and rely upon the inference in its motion to dismiss the case).

184 In re Asbury, Bankr. No. 08-21989, (Adversary No. 09-02012), 2011 WL 44911 (W.D. Mo. Jan. 6, 2011) (relying, in part, on a debtor's assertion of the Fifth Amendment as to false statements regarding assets, in determining that the chapter 7 debts were non-dischargeable under 523(a)(2)(B)); Chase Manhattan Bank, N.A. v. Frenville, 67 B.R. 858, 862 (Bankr. D. N.J. 1986) (using adverse inferences to deny dischargeability to certain debts where the debtor asserted the 5th Amendment to questions regarding their dischargeability). 


\section{Denial of Discharge}

The court may deny a discharge ${ }^{185}$ if the debtor has refused in the case to obey a lawful order of the court, to testify to selfincriminating matters after being granted immunity, or to respond to a question approved by the court without a proper assertion of the right against self-incrimination. ${ }^{186}$ If the debtor refuses a court ordered inspection of documents, there is no violation of the Code if the refusal is based on a proper assertion of the right against selfincrimination. ${ }^{187}$

Although a 2004 exam is another instance in which a debtor may assert the privilege, the bankruptcy court does not implicitly certify questions posed at a Rule 2004 examination. ${ }^{188}$ Thus, validly asserting a debtor's Fifth Amendment rights, without more, is not sufficient grounds to deny a discharge. ${ }^{189}$

\section{Inability to Testify in Other Proceedings}

Some consequences may affect the debtor's ability to testify in subsequent or contemporaneous (parallel) proceedings. For instance, if a debtor has refused to testify in prior proceedings based on a proper assertion of her rights, then the debtor may be barred from testifying in a later proceeding to any matters that were raised or could have been raised in the prior proceeding. ${ }^{190}$ The debtor's inability to testify in a later proceeding complicates strategic planning for future proceedings and makes assessment of the impact on anticipated proceedings difficult, if not impossible.

18511 U.S.C. $\$ 727$ (a)(1)-(12) (2006). The Chapter 7 discharge provision lists twelve grounds for objection to discharge. 11 U.S.C. § 1328(a) and (c) (2006) lists the grounds for objection to discharge in chapter 13. The grounds for objection to discharge in Chapter 12 are listed in 11 U.S.C. $\S 1228(a)$ and (c) (2006). The grounds for objection to the discharge for an individual debtor in Chapter 11 are listed at 11 U.S.C. $\$ 1141(\mathrm{~d})(3)$ (2006).

186 11 U.S.C. $\$ 727$ (a) (6) (2006).

187 See In re Bartel, No. 05-13134, 2009 WL 2461727, (Bankr. D. Mass. Aug. 10, 2009).

188 See In re Merena, 413 B.R. 792, 819 (Bankr. D. Mont. 2009), aff'd, In re Merena, No. 08-60066-7, 2009 Bankr. LEXIS 5531 (B.A.P. 9th Cir. Dec. 10, 2009).

189 See In re Ogden, No. UT-98-042, 1999 Bankr. LEXIS 1976, at *7 (10th Cir. B.A.P. $(\mathrm{Utah}))$.

${ }^{190}$ See, e.g., In re Nat'l Audit Def. Network, 367 B.R. 207, 216-17 (Bankr. D. Nev. 2007); United States v. Talco Contractors, Inc., 153 F.R.D. 501, 504-07 (W.D.N.Y. 1994); In re Hanson, 225 B.R. 366, 372 (Bankr. W.D. Mich. 1998), aff'd, No. 99-CV-55, 1999 U.S. Dist. LEXIS 8442 (W.D. Mich. June 1, 1999). 


\section{Contempt of Court and Imprisonment}

Another consequence the debtor may face is contempt of court. $^{191}$ A proper invocation of the privilege in one hearing does not automatically carry the privilege over to subsequent hearings. ${ }^{192}$ If the debtor asserts her privilege as to certain questions in one hearing, but testifies to those facts in a later hearing, she is not entitled to then reassert her privilege as to those matters. ${ }^{193}$ If the debtor disobeys a court order regarding those matters, supposing to rely on her previously asserted privilege, the court may use its contempt power to impose sanctions on the debtor, including fines and imprisonment. ${ }^{194}$

\section{Dismissal of the Bankruptcy}

Even if the debtor's Fifth Amendment assertion of the privilege is properly based, her case may be dismissed if her assertion hampers the trustee's ability to administer the bankruptcy estate. ${ }^{195}$ The court may dismiss the case with or without prejudice. If the court dismisses the case without prejudice, the debtor may file her petition after the threat of prosecution passes. ${ }^{196}$ Although this may seem like a reasonable solution, it is problematic for the debtor because the protection afforded against creditors' claims is lost when the automatic stay is no longer in place. In addition, there are negative implications for the debtor in attempting to file another bankruptcy within the succeeding year. ${ }^{197}$

191 11 U.S.C. $\$ 105$ (2006); FED. R. BANKR. P. 9020; see also supra note 118.

192 See In re Weerawat, No. 06-40098-JBR, 2007 WL 710160 (Bankr. D. Mass. Mar. $6,2007)$.

${ }_{193} I d$.

194 Id.; see also Martin-Trigona v. Belford, 732 F.2d 170, 173-74 (2d Cir. 1984); In re Sterling-Harris Ford, Inc., 315 F.2d 277, 278-79 (7th Cir. 1963), cert. denied, 375 U.S. 814 (1963).

195 See In re Blan, 239 B.R. 385, 397-98 (W.D. Ark. 1999); In re Moses, 792 F. Supp. 529, 532-36, 38 (Bankr. E.D. Mich. 1992); In re Fekos, 148 B.R. 10 (Bankr. W.D. Penn. 1992); Scarfia v. Holiday Bank, 129 B.R. 671, 675 (Bankr. M.D. Fla. 1990) (stating that a court could dismiss a petition sua sponte if it found that the trustee was unable to administer the estate), aff'd, 33 F.3d 1383 (11th Cir. 1994), cert. denied, 513 U.S. 1190 (1995); In re Connelly, 59 B.R. 421, 446-48 (Bankr. N.D. Ill. 1986).

196 See In re Pelko, 201 B.R. 331, 333-34 (Bankr. D. Conn. 1996).

197 11 U.S.C. $\$ 362$ (c) (3) (2006). The refiling of a consumer bankruptcy case by an individual after a dismissal within the preceding one year period of a pending consumer case other than under 11 U.S.C. $\$ 707$ (b) results in the termination of the stay with respect to the debtor on the 30 th day after the filing of the later case. The court may extend the stay only after notice and a hearing. The debtor has the burden of demonstrating that the filing of the later case is in good faith as to the creditors to be stayed. A case is presumed not to be in good faith, and the presumption must be overcome by clear and convincing evidence. 


\section{Implications in Criminal Proceedings}

Invocation or waiver of the privilege against self-incrimination in bankruptcy may have consequences in the criminal prosecution context as well. ${ }^{198}$ Absent immunity, plaintiffs may invoke the Fifth Amendment in response to incriminating questions during discovery or trial at any stage of the criminal process. ${ }^{199}$ Although a bankruptcy court may enforce a validly issued protective order, ${ }^{200}$ a grand jury subpoena may take precedence over a validly issued protective order. ${ }^{201}$ This leaves the debtor at risk during the pendency of the bankruptcy even when the incriminating information appears to be protected.

\section{Waiver of the Privilege}

A knowing and intelligent waiver of the right is not required in a noncustodial setting. ${ }^{202}$ Thus, it is possible for a debtor to lose the benefit of the privilege in the context of a bankruptcy without actual knowledge of the waiver because the setting is viewed as noncustodial. ${ }^{203}$

The Supreme Court has made it clear that the privilege is waived if it is not invoked. ${ }^{204}$ In other words, the privilege is not selfexecuting. Under certain circumstances, the waiver may be inferred from a witness' course of conduct or prior statements concerning the

198 See, e.g., In re Harris, 221 U.S. 274, 278-79 (1911) (Holmes, J.) ("That is one of the misfortunes of bankruptcy if it follows crime. The right not to be compelled to be a witness against oneself is not a right to appropriate property that may tell one's story.").

199 Grand Jury Proceedings (Williams) v. United States, 995 F.2d 1013, 1018 n.11 (11th Cir. 1993).

200 FED. R. Civ. P. 26(c); Martindell v. Int'l Tel. \& Tel. Corp., 594 F.2d 291 (2d Cir. 1979).

201 In re Grand Jury Subpoena served on Meserve, Mumper \& Hughes, 62 F.3d 1222, 1225 (9th Cir. 1995).

202 Garner v. United States, 424 U.S. 648 (1976).

203 Yarborough v. Alvarado, 541 U.S. 652 (2004) (holding that citizen is not in custody if a reasonable person in his situation would have felt free to "terminate the interrogation and leave"); Scarfia v. Holiday Bank, 129 B.R. 671, 675 (Bankr. M.D. Fla. 1990). Compare 11 U.S.C. $\$ 303$ (2006), (stating that the traditional rule that "a waiver will not be lightly inferred," applies in involuntary cases), with In re Hulon, 92 B.R. 670, 673 (Bankr. N.D. Tex. 1988) (stating that a waiver will also not be lightly inferred even in a voluntary case).

204 Rogers v. United States, 340 U.S. 367, 371 (1951) (stating that he privilege against self-incrimination is waived if it is not invoked) (citing United States v. Murdock, 284 U.S. 141, 148 (1931)). 
subject of the case. ${ }^{205}$ The waiver is not to be lightly inferred, and the courts indulge every reasonable presumption against finding a testimonial waiver. ${ }^{206}$ However, the mere fact that a waiver may be inferred creates a danger of inadvertent incrimination for the debtor. Courts will infer that an individual waived the privilege if the statements have created a significant likelihood that the finder of fact will be prone to rely on a distorted view of the truth, and the debtor had reason to know that her prior statements would be interpreted as a waiver. ${ }^{207}$

Filing bankruptcy schedules and statements may constitute a waiver of the privilege. ${ }^{208}$ In an adversary proceeding, filing an answer and responding to discovery requests may cause a waiver. ${ }^{209}$ Likewise, an affidavit operates like a testimonial statement and may be interpreted as a waiver. ${ }^{210}$ On the other hand, answering some questions prior to asserting the privilege will not necessarily operate as a waiver as to all questions presented. ${ }^{211}$

Because there is no clear line of demarcation to signal the unintentional waiver of the privilege by inference, the debtor is at risk to unwittingly allow access to both disclosed and undisclosed information. ${ }^{212}$ This may occur based on a witness's course of conduct or prior statements concerning the case and without an inquiry into whether or not the witness was aware of the privilege and

${ }^{205}$ In re Litton, 74 B.R. 557, 560 (Bankr. C.D. Ill. 1987).

206 In re Hulon, 92 B.R. at 673 (citing Klein v. Harris, 667 F.2d 274, 287 (2d Cir. 1981)) (stating that waiver is not to be lightly inferred, and courts indulge every reasonable presumption against finding a testimonial waiver; waiver inferred if (1) the statements have created a significant likelihood that the finder of fact will be left with and prone to rely on a distorted view of the truth; and (2) the debtor had reason to know that her prior statements would be interpreted as a waiver). But see Holiday Bank, 129 B.R. at 675 (stating that a debtor is before the Bankruptcy Court voluntarily and is not entitled to as much consideration in being compelled to testify as another witness would who had no interest in the proceeding).

207 In re Hulon, 92 B.R. at 673.

208 See In re Kroh, 87 B.R. 1004, 1005-06 (Bankr. W.D. Mo. 1988).

209 Id.

210 In re Edmond, 934 F.2d 1304, 1307-08 (4th Cir. 1991).

211 In re Jacques, 115 B.R. 272, 273 (D. Nev. 1990).

212 With regard to the requested items which may not have been previously disclosed, or to the extent that such commitment may not be legally binding, the privilege has been lost or waived for failure to have raised it timely. As the Supreme Court held: "[A] witness loses the privilege by failing to claim it properly even though the information being sought remains undisclosed when the privilege is claimed." In re Lederman, 140 B.R. 49, 54 (Bankr. E.D.N.Y. 1992) (quoting Garner v. United States, 424 U.S. 648,653 (1976)). 
chose to waive it consciously. ${ }^{213}$

\section{Depositions and 2004 Examinations}

The bankruptcy debtor is more at risk to unknowingly waive the privilege than the person in a custodial setting. The debtor may be deemed to have waived the privilege for purposes of a 2004 examination if she testifies at an earlier deposition on incriminating matters. This remains true even if her attorney did not advise her of the privilege or instruct her not to answer in the earlier deposition, and even if she was not aware at the time that the statements might be incriminating. ${ }^{214}$ In similar fashion, the debtor may have waived the privilege in bankruptcy proceedings by voluntarily answering questions and follow-up questions in earlier depositions regarding the same subject matter, despite the fact that counsel was not present at the depositions and the debtor was not informed of the privilege. ${ }^{215}$ In contrast, the failure to raise the privilege as an objection to subpoenaed documents has been held not to constitute a waiver. ${ }^{216}$ Consequently, the likelihood of inadvertent waiver of the privilege by the debtor can be seen to increase dramatically depending on the circumstances.

The debtor's ability to waive the privilege inadvertently due to lack of knowledge of its existence places the uninformed debtor at a serious disadvantage when compared to her more informed counterpart. The debtor's loss of the privilege through the inadvertence or neglect of counsel highlights the critical importance of educating the individual debtor and counsel about the privilege. Without disclosure to the debtor of the existence of the privilege, the probability of inadvertent waiver and any ensuing negative consequences falls disproportionately on the poor, the learning disabled, the uneducated, and the debtor represented by ineffective counsel, or those in our society who are least able to recover from the waiver and are most likely to suffer the consequences of waiver. ${ }^{217}$

\footnotetext{
213 In re Donald Sheldon \& Co., 193 B.R. 152, 162 (Bankr. S.D.N.Y. 1996) (citing Klein v. Harris, 667 F.2d 274, 287 (2d Cir. 1981)).

${ }_{214}$ In re A\&L Oil Co., 200 B.R. 21, 27 (Bankr. D.N.J. 1996).

215 In re Cotillion Invs., Inc., 343 B.R. 344, 351-52 (Bankr. S.D. Fla. 2006).

216 DG Creditor Corp. v. Dabah (In re DG Acquisition Corp.), 151 F.3d 75 (2d Cir. 1998).

217 One author characterizes the case law pertaining to learning disabled adults as follows:

Colorado v. Connelly held that although the defendant was mentally ill, his waiver was voluntary, thus valid. ... The majority reasoned that
} 
Aside from issues of due process and equal protection under the law, lack of notice of the privilege goes to the central issue of fundamental fairness that relates to the projected image and the perceived image of our system of justice as unbiased, impartial, and evenhanded.

Because legal entities are not considered persons for purposes of invoking the privilege, an individual's ability to claim the privilege may be affected by her prior testimony, actions and events regarding a legal entity. For instance, the debtor corporation's principal may not invoke her Fifth Amendment privilege to avoid answering questions at a 2004 examination ${ }^{218}$ when she has previously pled guilty in a criminal court on the issues. ${ }^{219}$ On the other hand, if the debtor's principal answers, "I don't know" or "I don't recall" to almost every question in an earlier deposition, the privilege may be preserved and claimed in a subsequent deposition despite the fact that it was not formally invoked in the earlier deposition. ${ }^{220}$

\section{Schedules}

The law is well settled that if the debtor fails to invoke the privilege at the time she files her schedules, the privilege is waived as to the facts shown, and the information will be admissible evidence against her in a criminal prosecution. ${ }^{221}$ Because the debtor's schedules are required and must be filed with the petition, any potential for incrimination should be explained to the debtor prior to the filing. Otherwise, the debtor may inadvertently waive the privilege, be incriminated irreversibly, face criminal prosecution based on her own supplied evidence, and suffer a denial of her discharge. As stated above, the fact that the debtor has not been properly advised by counsel or does not understand the privilege will

the sole concern of the Fifth Amendment, on which Miranda was based, is governmental coercion. The Court stated that under a due process analysis, beginning with Brown v. Mississippi, all cases deciding the constitutionality of a confession have contained a substantial element of police coercion. The Connelly Court stated that it is not the role of the Court to make sweeping inquiries into the state of mind of a criminal defendant who has confessed" unless there is evidence of police coercion.

Steven A. Greenburg, Learning Disabled Juveniles $\mathcal{E}$ Miranda Rights—What Constitutes Voluntary, Knowing, E् Intelligent Waiver, 21 GOLDEN GATE U. L. REV. 487, 494-95 (1991) (citations omitted).

218 FED. R. BANKR. P. 2004 ("The court may order the examination of any entity.").

219 In re Cassandra Grp., 338 B.R. 600, 604 (Bankr. S.D.N.Y. 2006).

220 Horowitz v. Sheldon, 193 B.R. 152. (Bankr. S.D.N.Y. 1996).

221 Ensign v. Pennsylvania, 227 U.S. 592, 599 (1913); Czarlinsky v. United States, 54 F.2d 889, 893 (10th Cir. 1931), cert. denied, 285 U.S. 549 (1932). 
not serve to avoid the waiver or minimize any damage resulting from the admissibility of the evidence. ${ }^{222}$

\section{The 341 Meeting}

The Court, in addressing the issue of waiver in the context of the first meeting of creditors, has spoken plainly. If the debtor voluntarily testifies at the 341 meeting without invoking the privilege, she may waive the privilege for later proceedings as to all matters related to the scope of her testimony, ${ }^{223}$ whether or not her waiver was knowing and intelligent. ${ }^{224}$ As noted above, waiver is inferred when the testimony creates a significant likelihood that the judge or jury will rely on a distorted view of the truth, and the debtor has reason to know that her prior statements will be interpreted as a waiver. ${ }^{225}$ Equally problematic is that a blanket invocation of the privilege is not a "proper assertion" and thus will not suffice to protect the debtor. ${ }^{226}$

\section{The Dangers of Parallel Proceedings}

A debtor faces a particular risk if she is exposed to parallel proceedings. Parallel proceedings are any simultaneous proceedings based on the same facts that serve as a basis for all of the claims. ${ }^{227}$

222 In re A\&L Oil Co., 200 B.R. 21, 27 (Bankr. D.N.J. 1996).

${ }^{223}$ Minnesota v. Murphy, 465 U.S. 420, 428 (1983) (noting that if the debtor voluntarily testifies at the 341 meeting without invoking the privilege, she may waive the privilege for later proceedings as to all matters related to the scope of her testimony).

${ }^{224}$ Garner v. United States, 424 U.S. 648, 654-55, n.9 (1976) (observing that knowing and intelligent waiver is not required in a noncustodial setting: "an individual may lose the benefit of the privilege [against self-incrimination] without making a knowing and intelligent waiver").

${ }^{225}$ In $r$ Hulon, 92 B.R. 670, 673-75 (Bankr. N.D. Tex. 1988) (stating that waiver is inferred if the "(1) the statements have created a significant likelihood that the finder of fact will be left with and prone to rely on a distorted view of the truth, and (2) the debtor had reason to know that her prior statements would be interpreted as a waiver of the privilege").

226 In re Connelly, 59 B.R. 421, 430 (Bankr. N.D. Ill. 1986) (finding that a blanket assertion of the privilege is not proper where debtor refused to answer 341 questions and had not scheduled creditors, debts, or assets, and liabilities, and where debtor provided no evidence of potential criminal investigation. The requisites for asserting the privilege are 1) a compelled disclosure; 2) found to be testimonial; and 3) incriminatory). See also In re Brandenberg, No. 06-30709, 2007 WL 117391, at *2 (Bankr. E.D. Tenn. Jan. 10, 2007) (finding that a blanket invocation is not sufficient).

${ }^{227}$ See 17 C.F.R. $\$ 12.24$ (defining parallel proceedings in the context of commodity and security exchanges as "[a] civil court proceeding, involving one or more of the respondents as a party, which is pending at the time the [other] complaint is filed and involves claims or counterclaims that are based on the same set 
This situation arises when the debtor is involved in a bankruptcy and a criminal proceeding at the same time. As explained below, the risk of adverse consequences remains even when the debtor claims the Fifth Amendment privilege against self-incrimination in both proceedings. ${ }^{228}$

Imagine a scenario in which a debtor in bankruptcy is also the subject of a criminal proceeding. If the debtor were involved in only the criminal proceeding, the prosecuting authority would be limited in its discovery of information. ${ }^{229}$ The trustee in bankruptcy, however, is entitled to a wider berth during discovery in bankruptcy because a debtor is mandated to file schedules and answer certain questions under oath. ${ }^{230}$ Therefore, the prosecuting authority could have access to information via the civil proceeding that it can use in the criminal proceeding. ${ }^{231}$

Under some circumstances, if the debtor's availability for examination by the trustee is in doubt, the debtor may be arrested by law enforcement officials, held in custody until a detention hearing, and released only upon certain conditions. ${ }^{232}$ If the debtor's attorney

of facts which serve as a basis for all of the claims in the reparations complaint"); Christian Babich, Comment, Parallel Proceedings: The Government's Double-Team Approach and the Degradation of Constitutional Protections, 11 LEWIS \& CLARK L. REv. 753, 754 (2007); Carl H. Loewenson, Jr., Parallel Proceedings, available at http:/ / www.mofo.com/files/Publication/b72e0c65-297f-455f-a9bb-6e0b63eb28c2 /Presentation/PublicationAttachment/bd3bc6f0-6563-4f4b-a3f2-0c18189b5d98 /04PLIDO.pdf (defining parallel proceedings as "two or more investigations or actions, concerning allegations arising from the same (or substantially the same) set of facts, proceed simultaneously or successively against the same or related parties").

${ }^{228}$ See Walter P. Loughlin, Fighting on Two Fronts: Parallel Proceedings and Challenges at the Intersection of Criminal and Civil Law, 32 Metropolitan Corporate Counsel (Oct. 1, 2006), available at http://www.metrocorpcounsel.com/pdf/2006/October /32.pdf (last visited Aug. 16, 2013) (outlining restrictions that courts have put on the government in parallel proceedings).

${ }^{229}$ See FED. R. CRim. P. 16; Middleton v. United States, 401 A.2d 109, 115 (D.C. Cir. 1979) (emphasizing limits on discovery rights to the government in criminal cases based on 18 U.S.C. $\$ 3500)$; see also infra Part 0

23011 U.S.C. $\$ 521$ (2006) (providing that the debtor shall perform certain duties including, but not limited to, filing a list of creditors, a schedule of assets and liabilities, a schedule of income and expenses, a statement of financial affairs, and a statement of intentions regarding secured property; as well as furnishing the trustee copies of payroll records, a Federal tax return for the most recent tax year, and photo identification).

231 One possible procedural remedy is for the bankruptcy court to stay the proceedings pending the outcome of the criminal proceedings so that the debtor can then proceed with confidence having finally resolved the related issues. See supra note 196 .

232 FED. R. BANKR. P. 2005 (c); 18 U.S.C. $\$ 3142(\mathrm{a})-(\mathrm{g})$ (2006). 
is not sensitive to these issues, the debtor may be exposed to the unnecessary risk of criminal liability. ${ }^{233}$ Although courts have reacted negatively to the government's invocation of both civil and criminal processes in parallel proceedings, such conduct is not prohibited, and still presents a risk of inadvertent disclosure to a debtor. ${ }^{234}$

\section{Protective Orders and Grand Jury Subpoenas}

The problematic nature of parallel proceedings can be seen in the procedural interplay between competing parties and the courts in separate civil and criminal actions. One example is when a grand jury subpoena duces tecum conflicts with a protective order. The Courts of Appeal have sometimes reached different results in similar situations. ${ }^{235}$

In one instance, a protective order enforced by the bankruptcy court to quash a subpoena duces tecum from the United States Attorney was deemed a "de facto grant of immunity,"236 despite the court's

$23368 \%$ of the 1,245,205 licensed attorneys in the U.S. are in private practice. AMERICAN BAR ASSOCIATION, Lawyer Demographics (2011), available at http://www.americanbar.org/content/dam/aba/migrated/marketresearch/Public Documents/lawyer_demographics_2012_revised.authcheckdam.pdf). The Martindale-Hubbell database lists 39,126 bankruptcy attorneys in the United States. Only 4,756 attorneys are listed as practicing both bankruptcy and criminal law. MARTINDALE.COM,http:/ / www.martindale.com/Results.aspx?ft=1\&frm=freesearch\&af s=Bankruptcy (last visited Aug. 16, 2013).) Arguably, those 4,756 attorneys are better prepared to raise the Fifth Amendment in bankruptcy proceedings because their practice would encounter it on a more regular basis.

${ }^{234}$ See Loughlin, supra note 228 at 32 (Oct. 1, 2006) http://www.metrocorpcounsel.com/pdf/2006/ October/32.pdf (last visited Aug. 16, 2013) (outlining restrictions that courts have put on the government in parallel proceedings).

235 Compare Martindell v. ITT, 594 F.2d 291, 296 (2d Cir. 1979) (“Absent a showing of improvidence in the grant of a Rule 26(c) protective order or some extraordinary circumstance or compelling need, a witness should be entitled to rely upon the enforceability of a protective order against any third parties."), with In re Grand Jury Subpoena, 836 F.2d 1468, 1478 (4th Cir. 1988) (finding that a valid protective order was not sufficient grounds to quash the subpoena duces tecum), In re Grand Jury Proceedings (Williams) v. United States, 995 F.2d 1013, 1020 (11th Cir. 1993) (stating that a Rule 26(c) protective order does not shield relevant information from a later grand jury investigation), and In re Grand Jury Subpoena Served on Meserve, Mumper \& Hughes, 62 F.3d 1222, 1227 (9th Cir. 1995) (adopting a per se rule that grand jury subpoenas take precedence over validly issued Rule 26(c) protective orders).

${ }^{236}$ In re Grand Jury Subpoena (Under Seal), 836 F.2d 1468, 1475 (4th Cir. 1988) (stating that a protective order, when enforced by the bankruptcy court to quash a subpoena duces tecum from the U.S. Attorney, works as a "de facto grant of immunity," however, 6003(a) states that the power to choose who may receive immunity is exclusively within the Executive Branch). 
acknowledgement that the power to grant immunity is reserved to the Executive Branch. $^{237}$ In one case, the court gave precedence to a grand jury subpoena over a valid protective order compelling the debtor to produce incriminating documents. ${ }^{238}$

In yet another case, the court held that absent a showing of improvidence in the grant of a protective order, exceptional circumstance, or compelling need, a witness is entitled to rely on the enforceability of a protective order against any third parties, including the government. ${ }^{239}$ The court held that a protective order should not be vacated or modified merely to accommodate the state's desire to inspect protected testimony for possible use in a criminal investigation, either as evidence or as the subject of a possible perjury charge. ${ }^{240}$

Even when the protective order is given precedence over the grand jury subpoena, the trier of fact may be permitted to draw an inference from the witness's silence. ${ }^{241}$ Nevertheless, the Court has held that the witness may not be compelled against a valid assertion of the Fifth Amendment privilege to repeat prior "immunized testimony" verbatim without a contemporaneous assurance of immunity. ${ }^{242}$ The Court's holding also extended to the compulsion of closely tracking testimony by the witness as it relates to prior "immunized testimony."

\section{Differences in Civil and Criminal Discovery}

Neither party is obliged to reveal much information during the discovery process in criminal proceedings. Under the Federal Rules, a defendant in a criminal proceeding is entitled to receive only his own statements, his prior criminal record, items that are "material to preparing the defense," items the government plans to use in its casein-chief, and items belonging to or obtained from the defendant. ${ }^{244}$

\footnotetext{
${ }^{237}$ In re Grand Jury Proceedings (Williams) v. United States, 995 F.2d 1013, 1020 (11th Cir. 1993) (stating that a Rule 26(c) protective order does not shield relevant information from a later grand jury investigation).

${ }^{238}$ In $r e$ Grand Jury Subpoena Served on Meserve, Mumper \& Hughes), 62 F.3d 1222, 1227 (9th Cir. 1995)

Martindell v. ITT, 594 F.2d 291, 296 (2d Cir. 1979); See also In re Grand Jury Subpoena (Roach), 138 F.3d 442, 445 (1st Cir. 1998).

240 Martindell, 594 F.2d at 296.

${ }^{241}$ In re Grand Jury Subpoena under seal, 836 F.2d 1468, 1476. (4th Cir. 1988), cert. denied, 487 U.S. 1240 (1988).

${ }^{242}$ Pilsbury Co. v. Conboy, 459 U.S. 248, 263 (1983).

243 Id.

244 FED. R. CRIM. P. 16 (a) (1); See Loewenson, supra note 227.
} 
Additionally, the defendant is required to disclose only evidence for her case-in-chief, and only where the defendant made a reciprocal request. ${ }^{245}$

In a civil action, however, both parties are entitled to all relevant, non-privileged material "reasonably calculated to lead to the discovery of admissible evidence." ${ }^{246}$ Thus, the scope of discovery in civil actions is often limited only by the zeal of the litigants. The evidentiary standard while perhaps excluding "witch hunts" may often fairly be characterized as a "fishing expedition." 247

Litigants are not required to prove that a line of inquiry will lead to admissible evidence. ${ }^{248}$ Instead, they are merely required to make a reasonable argument that the information could. ${ }^{249}$ In other words, access to information in the civil setting hinges on whether, in the estimation of the court, a litigant's particular inquiry may arguably capture information that points toward admissible evidence. While this discovery rule leaves some information off limits, it rightfully encourages the parties' search for the truth by providing a flexible, fluid, and somewhat unpredictable standard. ${ }^{250}$

\section{Discovery in Bankruptcy and the Risk of Loss of the Privilege}

In bankruptcy, the discovery provisions are similar to those of other civil proceedings, but distinctive in many ways. Each form of discovery creates an opportunity for loss of the privilege. For example, the Code requires the debtor to appear at a meeting convened by the United States Bankruptcy trustee for oral examination under oath. ${ }^{251}$ This meeting is similar to a public deposition and is referred to as the meeting of creditors or 341 meeting. The debtor in each case is subject to interrogation by any appearing creditor, the panel trustee, any examiner in the case, and

245 See Loewenson, supra note 227. But see Brady v. Maryland, 373 U.S. 83 (1963) (finding that the state has an obligation to furnish exculpatory evidence in its possession).

${ }^{246}$ FED. R. CIV. P. 26 (b) (1); see Loewenson, supra note 227, at 24-25.

247 See Wuterich v. Murtha, 562 F.3d 375, 386 (D.C. Cir. 2009); Hickman v. Taylor, 329 U.S. 495, 507 (1947).

${ }^{248}$ See Oppenheimer Fund, Inc. v. Sanders, 437 U.S. 340, 351 (1978) (emphasis added).

249 Id.

250 See Eggleston v. Chicago Journeymen Plumbers' Local Union No. 130, U. A., 657 F.2d 890, 903 (7th Cir. 1981).

25111 U.S.C. $\$ 341$ (2006). See supra Part III.C.3. 
the United States trustee. ${ }^{252}$

The scope of the examination is limited to "the acts, conduct, property, liabilities, and financial condition of the debtor, and any other matter that may affect the administration of the debtor's estate or to the debtor's right to a discharge. ${ }^{253}$ The Code description of the examination's scope appears restrictive by use of the phrase " $[\mathrm{t}]$ he examination ... may relate only to," yet when the provision is read in its entirety, the breadth of the permitted inquiry is notably sweeping and detailed. ${ }^{254}$ Refusal or inability of the debtor to attend the 341 meeting, to furnish information required by the Code, or to cooperate with the trustee may result in dismissal of the bankruptcy, conversion, or denial of the discharge. ${ }^{255}$

In addition to the requirement that the debtor testify at the 341 meeting, the court may order the examination of the debtor on the motion of any party in interest. ${ }^{256}$ Such examinations are often referred to as 2004 examinations and the scope of inquiry is the same as for the 341 meeting. ${ }^{257}$ The debtor may be compelled to attend the examination in the same manner as a witness at a trial in a United States District Court. ${ }^{258}$ The court may designate that the debtor be examined at any time and place. ${ }^{259}$

4. The Debtor's Failure to Appear, Incarceration, and the Need for Notice of the Privilege

The debtor may be held in custody and treated as a criminal in some instances even though no criminal charges have been filed. If the debtor is deemed necessary for the proper administration of the estate, and is alleged by affidavit to be avoiding examination, the

$252 \quad 11$ U.S.C. $\$ 343$ (2012).

253 FED. R. BANKR. P. 2004(b).

254 See id.

25511 U.S.C. $\$ 707$ (a) (1) (providing that the court may dismiss a case under Chapter 7 for cause including unreasonable delay by the debtor that is prejudicial to creditors); 11 U.S.C. $§ 521$ (i) (4),(j)(1) (providing that the court may decline to dismiss the case if the debtor tried in good faith to file the required information and that the best interests of the creditors would be served by administration of the estate; or if the debtor failed to file a tax return that becomes due after commencement of the case, the court shall convert or dismiss the case whichever is in the best interests of the creditors and the estate).

256 FED. R. BANKR. P. 2004(a) (emphasis added).

257 FED. R. BANKR. P. 2004(b); See supra Part III.C.1.

258 FED. R. BANKR. P. 2004(c); FED. R. BANKR. P. 9016 (incorporating by reference FED. R. CIV. P. 45 and thus providing for the form, issuance and service of subpoenas ad testificandum and duces tecum for trials, hearings, and depositions).

259 FED. R. BANKR. P. 2004(d). 
court may order law enforcement to bring the debtor to court without delay. ${ }^{260}$ The grounds for such an order include a sworn allegation that "there is reasonable cause to believe that the debtor is about to leave or has left [her] residence or principal place of business to avoid examination;" or has willfully disobeyed a subpoena or order to appear for examination. ${ }^{261}$

Whenever the debtor is found in a judicial district other than that from which the order was issued, the debtor may be taken into custody and removed either to the court issuing the order or the nearest available United States magistrate judge, bankruptcy judge, or district judge. ${ }^{262}$

If the judge finds that the person in custody is the debtor, the debtor is released on conditions to ensure her prompt appearance before the court that issued the order to compel attendance. ${ }^{263}$ In deciding conditions to assure the debtor's attendance for examination, obedience for further examination, and appearance for purposes of removal from another jurisdiction, the court is governed by the provisions and policies of the federal criminal code. ${ }^{264}$ The applicable section with regard to release or detention pending trial provides a number of factors that the court must consider with an eye towards the imposition of the least restrictive means of securing the attendance of the debtor. ${ }^{265}$ The debtor may, in this circumstance, be taken into custody, held until the detention hearing, and be dealt with in all respects as a criminal defendant pending her rebuttal of the allegations based on an affidavit. ${ }^{266}$ In this situation, the debtor is clearly in a custodial setting, albeit in a bankruptcy proceeding, and the debtor should be provided notice of her privilege against selfincrimination. ${ }^{267}$ Yet, despite the obvious need for notice, there is no

${ }^{260}$ FED. R. BANKR. P. 2005 (a).

$261 \quad I d$.

262 FED. R. BANKR. P. 2005(b).

263 Id

264 FED. R. BANKR. P. 2005 (c); see also 18 U.S.C. \$ 3146(a)-(b) (2006) (defining the offense of failure to appear and providing for punishment for failure to appear in criminal proceedings).

${ }^{265} 18$ U.S.C. $\$ 3142(\mathrm{a})-(\mathrm{g})$ (2006) (setting forth the court's procedure in detention hearings in criminal proceedings and the factors to be considered).

266 FED. R. BANKR. P. 2005 (c); see 18 U.S.C. \$ 3142(a)-(g) (2012) (setting forth the court's procedure in detention hearings in criminal proceedings and the factors to be considered).

267 Miranda v. Arizona, 384 U.S. 436, 444 (1966) (holding that an individual under custodial interrogation is entitled to warning (notice) of her rights to remain silent, end questioning, and to an attorney); Yarborough v. Alvarado, 541 U.S. 652, 
provision requiring that such notice be given.

\section{E. The Compulsion of Testimony}

As noted above, ${ }^{268}$ immunity is a term of art with many nuanced meanings that depend on context. The types of immunity that are relevant for the purposes of this Article are transactional immunity, use immunity, and derivative use immunity. Transactional immunity is a grant of immunity that shields the witness from any exposure to criminal liability that is related to a particular transaction. ${ }^{269}$ Use immunity is more limited than transactional immunity: the witness is protected only from the "use" of the witness' testimony in any criminal proceeding against the witness. ${ }^{270}$ The value of the privilege against self-incrimination is reduced when use immunity, rather than transactional immunity, is used to supplant the debtor's privilege because of the degree to which protection from criminal prosecution is lost. ${ }^{271}$ Derivative use immunity is closely related to use immunity. The use of evidence that is derived from the witness' testimony, "fruits" of the immunized testimony, is denied to the state when the debtor is given derivative use immunity. ${ }^{272}$

The law has changed over time as it relates to the type of immunity that suffices to justify the compulsion of testimony in the face of the proper assertion of the privilege. ${ }^{273}$ Under prior law, the debtor was allowed to refuse to answer incriminating questions even though the Bankruptcy Act (the Act) provided automatic limited $d^{274}$ use

659 (2004) (holding that citizen is not in custody if a reasonable person in his situation would have felt free to "terminate the interrogation and leave").

268 See supra Part I.E.

269 See, e.g., Counselman v. Hitchcock, 142 U.S. 547, 586 (1892).

270 Murphy v. Waterfront Comm'n of N.Y. Harbor, 378 U.S. 52, 103 (1964), abrogated by United States v. Balsys, 542 U.S. 666 (2007).

271 Kastigar v. United States, 406 U.S. 441, 466-67, (1972) (Douglas, J., dissenting).

${ }^{272}$ Murphy, 378 U.S. at 79 ("[W]e hold the constitutional rule to be that a state witness may not be compelled to give testimony which may be incriminating under federal law unless the compelled testimony and its fruits cannot be used in any manner by federal officials in connection with a criminal prosecution against him.").

273 Counselman, 142 U.S. at 547 (required transactional immunity); Kastigar, 406 U.S. at 441 (1972) (overruling Counselman on that point and substituted use and derivative use immunity as a sufficient basis to compel testimony as against an assertion of the privilege).

274 The immunity was limited in two ways. The protection afforded was restricted to the debtor's testimony, not documents, and even the testimony could be used in hearings on objections to discharge. United States v. Seiffert, 501 F.2d 974, 981 (5th Cir. 1974) ("Nor does that immunity extend, as the appellant would have it, to certain of his books and records introduced in evidence against him at trial."); 11 
immunity. ${ }^{275}$ The Act was the immediate predecessor to the modernday Code and required the debtor to testify in all circumstances. ${ }^{276}$ The debtor's refusal to answer any material question could result in the denial of the debtor's discharge. ${ }^{277}$ The debtor was expected to be forthcoming even on incriminating matters because the Act granted use immunity automatically. ${ }^{278}$

The Court has altered the type of immunity necessary to compel testimony in the face of a proper assertion of the privilege. The Court has moved from a rule, mandating transactional immunity in exchange for "immunized testimony" ${ }^{\text {" } 79}$ to a rule that permits the compulsion of privileged testimony through use immunity and derivative use immunity. ${ }^{280}$ Debtors, debtors' counsel, and the courts have been affected in dramatically different ways by the Court's decisions and the exceptions to the exercise of the privilege that allow compulsion of incriminating documents after assertion of the privilege without a grant of immunity. ${ }^{281}$

U.S.C. 25(a) (10) (repealed 1978) (" $[\mathrm{N}]$ o testimony, or any evidence which is directly or indirectly derived from such testimony, given by him shall be offered in evidence against him in any criminal proceeding, except such testimony as may be given by him in the hearing upon objections to his discharge. . . " (emphasis added)).

275 In $r e$ Rosser, 96 F. 305 (E.D. Mo. 1899) (finding that refusal was allowed where debtor refused to answer certain questions before a referee on the ground of selfincrimination, despite the fact that $\S 7$ of the Bankruptcy Act gave use immunity to the debtor).

27611 USC $\$ 25(\mathrm{a})(10)$ (repealed 1978) (finding that a debtor is required to testify in all circumstances).

27711 USC $\$ 32(\mathrm{c})(6)$ (repealed 1978) (finding that refusal to answer a material question was grounds for a denial of a discharge).

278 USC $\$ 25(\mathrm{a})(10)$ (repealed 1978) (discussing statutory grant of use immunity).

279 Counselman v. Hitchcock, 142 U.S. 547, 585-86 (1892).

280 Kastigar v. United States, 406 U.S. 441, 462 (1972).

281 Compulsion of the production of incriminating documents has been allowed after proper assertion of the privilege and without a grant of immunity thus creating exceptions to the exercise of the privilege under various theories including a corporate records exception, public records exception, a required records exception, and an exception based on the assumption of custodial duties under a required regulatory regime. See Wilson v. United States, 221 U.S. 361, 380 (1911) (finding that if corporate papers are records of an organization or "collective entity" with a duty to keep records, no Fifth Amendment privilege attached); In re Grand Jury Proceedings, 119 B.R. 945, 949-50 n.4 (E.D. Mich. 1990) (finding that documents that Chapter 7 trustee had to maintain in his official capacity as trustee of bankruptcy estate qualified as "public records," which trustee could be required to produce under public records exception to Fifth Amendment); In re Grand Jury Subpoena Duces Tecum Served Upon Underhill, 781 F.2d 64, 67(6th Cir. 1986); Balt. City Dept. of Social Servs v. Bouknight, 493 U.S. 549, 555 (1990) (finding that a person may not claim the Amendment's protections based upon the incrimination 
1. Procedure for the Grant of Immunity

Under Part V of Title $18,{ }^{282}$ whenever a witness refuses to testify in a court proceeding based on her privilege against selfincrimination, an Assistant United States Attorney must first seek the U.S. Attorney's permission to refer the matter to an Assistant Attorney General (AAG), and then must obtain the approval of the AAG for the Criminal Division or the AAG for the division of the Department of Justice accountable for the case. ${ }^{283}$ If an AAG other than the AAG for the Criminal Division approves the request, the approval of the AAG for the Criminal Division is also necessary. ${ }^{284}$ An Assistant U.S. Attorney may then file the necessary motion in the District Court requesting an order granting the debtor immunity related to that testimony. ${ }^{285}$

If use and derivative use immunity are granted, the debtor may not lawfully refuse to testify to those issues. ${ }^{286}$ However, no testimony or other information compelled under the order, or any information directly or indirectly derived from such testimony or information may be used against the debtor in any criminal case, except for prosecution for perjury, giving a false statement, or otherwise failing to comply with the order. ${ }^{287}$ The protection that the grant of use and derivative use immunity affords the debtor from exposure to criminal liability is beneficial but problematic.

As noted above, use and derivative use immunity combined do not provide the debtor the same level of protection as transactional immunity and leave the debtor open to criminal sanctions based on

that may result from the "unadorned act of producing the child" or the "contents or nature of the thing demanded").

28218 U.S.C. $\$ \S 6001-6005$ (2006).

283 U.S. DeP’T OF Justice, U.S. AtTorney's Manual § 9-23. 110-310 (1992). As an alternative, informal or "hip pocket" immunity may be granted. The debtor should still be cautious of this form of immunity as it arises from no statutory provision, is discretionary with the prosecutor, and is not binding on any other jurisdiction. Courts have frowned upon the practice, but have accepted it as the promise not to prosecute is of value. United States v. Anderson, 778 F.2d 602, 606 (10th Cir. 1985) ("The propriety of using informal immunity has been frequently upheld."); United States v. Winter, 663 F.2d 1120, 1133 (1st Cir. 1981), cert. denied, 460 U.S. 1011 (1983); United States v. Librach, 536 F.2d 1228, 1230 (8th Cir. 1976), cert. denied, 429 U.S. 939 (1976); see also United States v. Peister, 631 F.2d 658, 662-63 (10th Cir.1980), cert. denied, 449 U.S. 1126 (1981).”).

284 U.S. DEP'T OF JUSTICE, U.S. ATtORNEY's MANUAL § 9-23.130 (1992).

28518 U.S.C. $\$ \S 6002-6003$ (2006); see also U.S. DEP’T OF JUSTICE, U.S. ATTORNEY'S MANUAL $§ 9-23,310$ (1992).

$286 \quad 18$ U.S.C. $\$ 6002$ (2006).

287 Id. 
evidence unrelated to her testimony. In addition, the grant of immunity does not prevent the use of the debtor's testimony to prove elements of a crime in the bankruptcy proceeding as a basis for denial of discharge. ${ }^{288}$ In short, the grant of use and derivative use immunity in bankruptcy proceedings may lessen the possibility of bringing criminal charges, but it does not fully protect the debtor from criminal punishment, civil liability, or a denial of discharge.

Considering the disadvantages the debtor faces if she testifies after the court issues a grant of immunity, the debtor might still be tempted to refuse to testify. That also is problematic. The debtor's refusal to testify after a grant of use and derivative use immunity is grounds for a global objection to discharge and a basis for the court's denial of discharge. ${ }^{289}$ In addition, the debtor's refusal to testify after a grant of immunity may subject her to contempt proceedings and sanctions including fines and imprisonment. ${ }^{290}$ In other words, whether the debtor testifies after a grant of use and derivative use immunity, or whether the debtor refuses to testify after a grant of use immunity, the debtor risks going to jail and a denial of discharge. ${ }^{291}$ What may seem a Hobson's Choice ${ }^{292}$ is, for the truly innocent debtor, more akin to Sophie's Choice, ${ }^{293}$ and commentators explored this but Congress and the courts largely ignore or accept it. ${ }^{294}$

If the United States Attorney does not request immunity for the debtor, or if immunity is not offered, then the debtor may refuse to testify, invoking her Fifth Amendment privilege against self-

288 In re Leslie, 119 F. 406, 409 (N.D.N.Y. 1903).

28911 U.S.C. $\$ 727$ (a) (6) (2012).

290 In re Martin-Trigona, 732 F.2d 170 (2d Cir. 1984).

291 See Garrity v. New Jersey, 385 U.S. 493, 496 (1967) (holding that in a prosecution for conspiracy to obstruct justice a choice between self-incrimination and job forfeiture was coercion that violated the privilege against self-incrimination).

${ }^{292}$ A Hobson's Choice is a free choice with only one option offered.

293 The term Sophie's Choice, after the novel and film of the same name, refers to a choice between two unbearable options. Sophie's Choice was undeniably more horrific than the scenario posed here for Sophie Debtor.

${ }^{294}$ Craig P. Gaumer \& Charles L. Nail, Jr., Truth of Consequences: The Dilemma of Asserting the Fifth Amendment Privilege Against Self-Incrimination in Bankruptcy Proceedings, 76 Neb. L. REv. 497, 559-60 (1997); Laurie K. Jones, Bankruptcy Courts and the Reluctant Witness: Why A Rule 26(c) Protective Order Is Not A Substitute for A Grant of Immunity When the Witness Refuses to Testify Based Upon Fear of Criminal Prosecution, 25 CAL. BANKr. J. 180, 182 (2000); Allan B. Diamond \& Erin E. Jones, Avoiding Litigation Pitfalls: An Introduction to the Fifth Amendment Privilege Against Self-Incrimination in Bankruptcy Proceedings, AM. BANKR. Inst. J., 20, 66 (2008); Leonard M. Shulman \& Kara Germane, A Debtor's Right to Silence in A Bankruptcy Proceeding, Orange County LAW., 46, 47 (2005). 
incrimination, and retain her right to a discharge. ${ }^{295}$ A debtor may invoke her right in response to incriminating questions both during discovery and at trial. ${ }^{296}$ As noted earlier, current bankruptcy law under the Code specifically provides for the preservation of the privilege; though unlike the previous Act, the grant of immunity is not automatic. ${ }^{297}$

\section{Practical Considerations}

The statistical probability of an offer of immunity is small. ${ }^{298}$ It is unlikely that a request for immunity by the trustee or the United States Attorney will be made, and any request may be denied by the Assistant U.S. Attorney General or the district court. Often there is a sense that a successful objection to discharge can be accomplished without the testimonial information that a grant of immunity would compel. Likewise, a United States Attorney may prefer to prosecute with the available evidence rather than suffer the proof burden of establishing that the state's case is not comprised of the debtor's testimony or any fruits (evidence) derived from that testimony.

\section{The Form of Reform to Protect the PRIVILEGE}

\section{A. Revision of Official Form B201A Notice to Individual Debtors}

The pro se debtor and the debtor with counsel need notice of the Fifth Amendment privilege against self-incrimination. All debtors should be advised of the existence of the privilege and should be given some sense of its scope and its limitations. Pre-filing disclosures relevant to invocation and waiver and the potential consequences of each would serve the purposes of the rules of bankruptcy procedure and promote the ends of justice. ${ }^{299}$ Some may seize on this proposal as a Miranda warning for the debtor and argue it exceeds the mandate of Miranda because the proceedings are not custodial or

295 In re Hulon, 92 B.R. 670, 673 (Bankr. N.D. Tex. 1988); In re Girdaukas, 92 B.R. 373, 376 (Bankr. E.D. Wis. 1988); In re Connelly, 59 B.R. 421, 426 \& 430 (Bankr. N.D. Ill. 1986); Chrysler Capital Corp. v. Salzman (In re Salzman), 61 B.R. 878, 889 (Bankr. S.D.N.Y. 1986); Turner v. Wlodarski (In re Minton Group, Inc.), 43 B.R. 705, 709 (Bankr. S.D.N.Y. 1984).

${ }^{296}$ Grand Jury Proceedings (Williams), 995 F.2d 1013, 1018 n.11 (11th Cir. 1993).

297 U.S.C. $\$ 344$ (2006).

298 This assertion is based on the Author's observations as a deputy prosecuting attorney, bankruptcy trustee, judge, and practitioner for over 36 years and conversations with trustees and government attorneys.

299 See generally, FED. R. BANKR. P. 1001. 
criminal. Aside from the fact that the proceedings may be custodial $^{300}$ the Author's thesis is not that Miranda should apply even in a noncustodial setting. The Author's thesis is that the privilege exists as a constitutional right in bankruptcy, and that it has value and utility to debtors. Therefore, as a matter of adjudicative policy, the Court should compel disclosure of the right to claim the privilege.

To accomplish this result, a new proposal for an Official Form should be promulgated by the Judicial Conference of the United States pursuant to its authority under the Federal Rules of Bankruptcy Procedure (hereinafter "the Rules") Rule 9009. In the interim, the Director of the Administrative Office of the United States Courts should issue additional forms for use under the Code pursuant to Rule 9009 of the Rules. ${ }^{301}$ The proposed form should be construed to be consistent with the rules and the Code and secure the "just, speedy, and inexpensive determination of every case and proceeding.",302

\section{The Status Quo}

Current law mandates that the Official Forms offer several notices and warnings to the consumer debtor. The first notice requires disclosure of the opportunities for credit counseling, budget analysis, and instruction on financial management. ${ }^{303}$ The second notice advises the consumer debtor of the four chapters of the Bankruptcy Code that may be available as filing options and briefly outlines the nature of each chapter. ${ }^{304}$ In the third numbered paragraph of the Official Form, the debtor is warned that there are criminal penalties for the fraudulent concealment of assets, perjury and false swearing, which include fines, imprisonment, or both. ${ }^{305}$

This notice regarding criminal conduct and penalties is

$300 \quad$ See supra Part III.D.4

301 The current Director is Judge Thomas F. Hogan. Judge Hogan is the chief administrative officer for the federal courts and secretary to the Judicial Conference of the United States. For information on the Administrative Office of the United States Courts. See United States COURTs, Bankruptcy Courts, http://www.uscourts.gov/FederalCourts/UnderstandingtheFederalCourts/Bankrupt cyCourts.aspx.

302 FED. R. BANKR. P. 1001.

30311 U.S.C. $§ 342$ (b) (2012), FeD. R. BANKR. P. 9009; see Official Form B201A, available at http://bankrupt.com/misc/canb10-71819.pdf.

30411 U.S.C. § 342(b) (2012), Fed. R. Bankr. P. 9009; see Official Form B201A, available at http://bankrupt.com/misc/canb10-71819.pdf.

30511 U.S.C. $\$$ 342(b) (2012), Fed. R. Bankr. P. 9009; see Official Form B201A, available at http://bankrupt.com/misc/canb10-71819.pdf. 
immediately followed by the disclosure that "[a]ll information supplied by a debtor ... is subject to examination by...the Department of Justice." "Finally, in a section labeled "WARNING," Official Form B201A concludes by disclosing that Section 521(a) (1) of the Code requires the debtor to promptly file detailed information regarding creditors, assets, liabilities, income, expenses, and her general financial condition. This paragraph warns the debtor that her bankruptcy case may be dismissed if this information is not filed with the court within the time deadlines set by the Code, Rules, and local rules. The debtor is directed to a website address for Official Form B200 which provides a listing of the documents and deadlines. ${ }^{307}$

The debtor's attorney must certify delivery of the required notices and the debtor must affirm that she has received and read the notices. ${ }^{308}$ The requirement of these and other notices to the debtor by Congress and the Court make clear the importance current law places on the disclosure to the debtor of the opportunities to avoid bankruptcy, potential bankruptcy filing options, the possibilities for criminal exposure, criminal penalties, the availability of documents for inspection by the DOJ, the requirements for disclosure, and risk of dismissal. ${ }^{309}$ It seems illogical, given the present breadth and depth in the level of specificity of notices to the debtor, that the Code, Rules and Official Forms are strangely silent regarding the debtor's privilege against self-incrimination. This is particularly true in light of the evidentiary value of the privilege and its relative importance when compared to the notices pertaining to statutory rights and criminal penalties.

\section{A Modest Proposal for Change}

As a policy matter, the notion that each of these mandated notices and warnings are more critical to the consumer debtor than the disclosure of the privilege is untenable. Although disclosure of the existence of the privilege is not required under current law, there is no prohibition of notice. When consideration is given to the

30611 U.S.C. § 342(b) (2012), Fed. R. Bankr. P. 9009; see Official Form B201A, available at http:/ / bankrupt.com/misc/canb10-71819.pdf.

30711 U.S.C. $§ 342$ (b) (2012), Fed. R. Bankr. P. 9009; see Official Form B201A, available at http://bankrupt.com/misc/canb10-71819.pdf.

30811 U.S.C. $\$ 342$ (b) (2012); FED. R. BANKR. P. 9009; see Official Form B201B, available at http://bankrupt.com/misc/canb10-71819.pdf.

30911 U.S.C. $§ 342$ (b) (2012); FED. R. BANKR. P. 9009; see also Official Form B201A, available at http://bankrupt.com/misc/canb10-71819.pdf. 
constitutional origins and evidentiary value of the privilege, particularly to the pro se debtor, the absence of notice is alarming and difficult to understand. ${ }^{310}$ Although traditionally in bankruptcy pro se litigants are assumed to be less educated than debtors who are represented, the opposite is true. The pro se debtor is also more educated than the general pro se population. ${ }^{311}$ The higher level of education, coupled with the publication and availability of the official forms, engenders hubris in the consumer debtor. The resulting overconfidence, when combined with the easy availability of the forms, tempts the pro se debtor to file a complex federal proceeding that is beyond the debtor's expertise. ${ }^{312}$ As a consequence, the pro se debtor often discovers belatedly that the filing was ill advised and will be dismissed or have unintended results. The proof of this phenomenon can be seen in the relative success rates between pro se and represented filers in obtaining a discharge. ${ }^{313}$ Pro se filers are ten times less likely to obtain a discharge. ${ }^{314}$

A procedure for disclosure of the right to the privilege currently

310 Studies show the demographics for pro se debtors in state courts include a higher incidence among the young, the poor, the less educated, women and minorities. Ayn Crawley, Trends in Pro Se Litigation, Md. Legal Assistance NeTwork, http://www.courts.ca.gov/partners/documents/HelpThemselves.pdf (last visited Aug. 16, 2013) (reporting that statewide statistics of over 40,000 self-represented users of programs in Maryland in 2002 indicated that $60 \%$ were women; $44 \%$ described themselves as African American and 9\% as Hispanic; the vast majority had modest incomes); see also Connie J.A. Beck et al., Divorce Mediation With and Without Legal Representation: A Focus on Intimate Partner Violence and Abuse, FAMILY COURT Rev., 48(4): 631-645, Oct 2010, http://onlinelibrary.wiley.com/doi/10.1111/j.17441617.2010.01338.x/pdf (last visited Nov. 5, 2013); see also Chanley S. Painter, Exploring the Problem of Self-Represented Litigants in Arkansas Civil Courts, Arkansas Access to Justice Commission in partnership with the Clinton School of Public Service (2011) http://www.arkansasjustice.org/sites/default/files/file\%20attachments /Capstone\%20Report\%20-\%20AAJC\% 20Final.pdf (last visited Aug. 16, 2013).

311 Angela LitTwin, Broke: How Debt Bankrupts the Middle Class 157-58 (Katherine Porter ed., 2012). Results based on the 2007 Consumer Bankruptcy Project; see Joseph Callanan, Pro Se Bankruptcy Filings Growing Faster than Other Debtor Relief, LitigATION News (Dec. 29, 2011), http://apps.americanbar.org/litigation /litigationnews/top_stories/010312-pro-se-bankruptcy-growing.html (offering explanations of the differences in education level between pro se debtors and other pro se litigants).

312 Joseph Callanan, Pro Se Bankruptcy Filings Growing Faster than Other Debtor Relief, LitigATION NEwS (Dec. 29, 2011), http://apps.americanbar.org/litigation /litigationnews/top_stories/010312-pro-se-bankruptcy-growing.html (offering explanations of the differences in education level between pro se debtors and other pro se litigants).

${ }_{314}^{313} I d$. 
exists, albeit in the context of another federal civil proceeding. ${ }^{315}$ For more than two decades, the federal administrative rules have been used to mandate that notice of the privilege be given by the Department of Justice to respondents in proceedings to assess civil penalties for possession of small amounts of certain controlled substances. $^{316}$ Thus, there is a precedent, a form, and a format in use by federal authorities in civil proceedings that provide a template for the construction of a similar notice in the bankruptcy context. ${ }^{317}$ The adoption of the wording presently in use could easily be adapted to provide a new category for the proposed revision of Official Form B201A to read as follows:

4. Notice to the individual consumer debtor of the right to invoke privileges, including the privilege against selfincrimination: Any statement given during the course of any proceedings or any documents filed in the proceedings may be used against the person in this or any other proceeding, including any criminal prosecution. Each individual debtor may be able to assert a privilege, such as the privilege against self-incrimination. Any petition, schedule, statement, or pleading required to be filed or contested by the debtor in a responsive pleading shall include a statement that the respondent admits, denies, does not have and is unable to obtain sufficient information to admit or deny each allegation, or that an answer to the allegation is protected by a privilege, including the privilege against self-incrimination. A statement of lack of information or a statement that the answer to the allegation is privileged shall have the effect of a denial.

This simple proposal for an addition to a revised Official Form B201A will go far in eliminating the dangers that presently lurk for the uninformed debtor. Whether the individual is an uneducated pro se debtor or a represented debtor whose attorney has neglected to inform her of her rights, the harm is the same. No debtor should be denied her Fifth Amendment right to the privilege against self-

31521 U.S.C. $\$ 844$ (a) (2006); 28 C.F.R. $\$ 76.4$ (b) (2) (2007) (stating that the Notice of Intent to Assess a Civil Penalty will advise the respondent that any statement given may be used against the person in any proceeding, including criminal prosecution and that the respondent may be able to assert a privilege such as the privilege against self-incrimination).

31621 U.S.C. $\$ 844(\mathrm{a})(2006)$.

${ }^{317}$ Id.; 28 C.F.R. 76.9 (c) (2)-(3) (2007) (providing that the content of any answer filed by a respondent may contain a statement that an answer to the allegation is protected by a privilege, including the privilege against self-incrimination, and that such a statement shall have the effect of a denial). 
incrimination due to personal ignorance or professional neglect.

The Court, under its inherent authority and pursuant to federal law, ${ }^{318}$ should adopt a revised Official Form B201A to provide notice of the debtor's privilege against self-incrimination as numbered paragraph 4 of the current form. The form should be promulgated by the Judicial Conference of the United States pursuant to its authority under Rule 9009 of the Rules. ${ }^{319}$ The revised form would help to insure that the debtor is aware of the privilege prior to filing. In the interim, the Director of the Administrative Office of the U.S. Courts should issue the revised form for use under the Code. ${ }^{320}$ The Court's action is necessary to afford the debtor, who appears before the DOJ trustee in bankruptcy, the same notice that is currently provided to a civil litigant who is targeted by the DOJ for an assessment of civil penalties for possession of certain controlled substances. ${ }^{321}$

\section{B. The Rulemaking Process}

Proposed amendments to the Federal Rules of Bankruptcy are handled by a time-proven and statutorily sanctioned process. ${ }^{322}$ The process is the same for proposed amendments to the Federal Rules of Appellate, Civil, and Criminal Procedure, and the Federal Rules of Evidence. ${ }^{323}$ There are seven steps in the process of amending the bankruptcy forms. The first step in the process is the initial consideration by the Advisory Committee. ${ }^{324}$ The publication and public comment period is next, followed by consideration of the public comments and final approval by the Advisory Committee. The fourth step is the approval by the Standing Committee, followed by Judicial Conference Approval. Next, the United States Supreme

31828 U.S.C. $\$ 2075$ (2006).

319 FED. R. BANKR. P. 9009.

$320 \quad$ Id

321 See 11 U.S.C. $\$ 342$ (2006); In re Litton, 74 B.R. 557, 560 (Bankr. C.D. Ill. 1987).

${ }^{322}$ Rules Enabling Act 28 U.S.C. $\$ \S ~ 2071-2077$ (2006), available at, http://www.uscourts.gov/RulesAndPolicies/rules/about-rulemaking

/how-rulemaking-process-works/overview-bench-bar-public.aspx.

323 United STATES COURTS, Federal Rules of Practice and Procedure, http://www.uscourts.gov/RulesAndPolicies/rules/about-rulemaking

/how-rulemaking-process-works.aspx (last visited Aug. 16, 2013).

324 UNiTED STATES COURTS, http://www.uscourts.gov/uscourts/RulesAndPolicies /rules/Members_List_Oct_2011.pdf (last visited Aug. 16, 2013) (listing the composition of the Advisory Committee on Bankruptcy Rules and contact information). 
Court must give its approval, and finally there must be Congressional Review and the implementation of the rules. ${ }^{325}$

As of the date of this publication, there are no completed rules or pending rules that address the issues surrounding the provision of notice to individual debtors of their Fifth Amendment privilege against self-incrimination. ${ }^{326}$ All of those involved in the rulemaking process have a tremendous responsibility. Debtors and lawyers, no less than other citizens, are beneficiaries of the Court's efforts to preserve and protect the rights of all parties in our system of justice. That effort includes the preservation and protection of the rights of debtors and the institutionalization of principles of fundamental fairness in the bankruptcy courts.

\section{CONCLUSION}

The adverse consequences for even one truly innocent debtor, however seemingly guilty, are disproportionately harsh. The protection of the privilege for the factually guilty is equally important and its loss, equally harsh. This is particularly true when the protection of every debtor from the inadvertent loss of the privilege can be so easily accomplished. The current system perpetuates nondisclosure and allows the unrepresented, uneducated debtor to be victimized by her own ignorance or the inadvertence of counsel. In both instances, the integrity and respectability of our system of justice are needlessly impugned.

The cost of adding a disclosure to the debtor regarding her Fifth Amendment privilege against self-incrimination means revising a mass produced form to include a fourth paragraph on the lower half of the second page in an otherwise blank space. This would be a minimally burdensome measure that would go far in preserving one of our most fundamental constitutional rights. The preservation of

325 One may argue that any change in Official Form B201A must be preceded by a statutory amendment to 11 U.S.C. $\$ 342$ (b) because that provision is the statutory authority for the publication of the notices contained in B201A. The Author concedes that the argument is not without merit, and that statutory amendment is desirable; however, the disclosure of the privilege included in the DOJ notice was authorized by administrative rule without the necessity of Congressional action. The counterargument is that because the privilege originates in the Constitution, no statutory authority is needed for the Court to make that fact known as a matter of adjudicatory policy through its rulemaking authority.

${ }^{326}$ Pending Rules Amendments, United STATES Courts, http://www.uscourts.gov/rulesandpolicies/rules/pending-rules.aspx (last visited Aug. 16, 2013). 
that right and its value to an innocent debtor, however seemingly guilty, is immeasurable. The value to the factually guilty is critical as well.

Only when the innocent debtor who is seemingly guilty receives notice of her constitutional right to the evidentiary privilege against self-incrimination will the rules in bankruptcy proceedings, "secure the just ... determination of every case and proceeding." Only then will the privilege take its rightful place alongside bankruptcy's mandated notices regarding the availability of credit counseling services, bankruptcy chapter filing options, bankruptcy crimes, and the availability of bankruptcy papers to law enforcement officials. Until that time pro se debtors and debtors with counsel will remain vulnerable to the loss of the privilege in criminal proceedings because of nondisclosure. The existing form highlights the opportunity for law enforcement review, investigation, and prosecution of all documents and related matters. ${ }^{327}$ Without notice, debtors will face the loss of a privilege scrupulously preserved and guarded throughout our history in the protection of the constitutional rights of even the worst criminals.

The debtor, who may be among our poorest citizens, should not discover in the course of her bankruptcy that she has unwittingly forfeited one of her fundamental constitutional rights. ${ }^{328}$ To avoid this result, Official Form B201A should be revised in a simple, straightforward way by providing notice of the privilege to all individual debtors prior to the time of filing.

A revision of Official Form B201A to include notice of the privilege will benefit the attorneys who represent debtors as well. History reveals how fluid the privilege and the law surrounding it can be. ${ }^{329}$ The privilege, like the law itself, is a moving stream with waters that rise and recede and sometimes overflow the banks to course where they will. Skilled counsel, like experienced boatmen, do well to observe the weather before braving the currents with those entrusted to their care.

32711 U.S.C. $\$ 342$ (b) (2006); FED. R. BANKR. P. 9009; Official Form B201A, available at http://bankrupt.com/misc/canb10-71819.pdf.

328 Total consumer (nonbusiness) filings for the 12-month period ending March 31, 2012, were 1,320,613, comprising $97 \%$ of all bankruptcy filings. See Table F-2, U.S. Bankruptcy Courts-Business and Nonbusiness Cases Commenced, by Chapter of the Bankruptcy Code, UNITED STATES COURTS, http://www.uscourts.gov/uscourts /Statistics/BankruptcyStatistics/BankruptcyFilings/2012/0312_f2.pdf (last visited Oct. 7, 2013).

${ }^{329}$ See supra Part I.E. 


\section{APPENDIX A}

Trustee: Do you solemnly swear or affirm to tell the whole truth? Sophie: I do.

Trustee: Please state your name and address for the record. Sophie: My name is Sophie Debtor and I'm from Hard Luck Town.

Trustee: Did you read your voluntary petition and schedules?

Sophie: Yes.

Trustee: Does it include all your property?

Sophie: Yes.

Trustee: Have you listed all of your debts?

Sophie: No. I recently discovered a credit card bill.

Trustee: What's the bill for?

Sophie: Cash advances and jewelry.

Trustee: When were these transactions?

Sophie: Within the past 60 days.

Trustee: How much were they?

Sophie: The advance was $\$ 1000$ and the jewelry was also $\$ 1000$.

Trustee: Do you have the cash or the jewelry?

Sophie: No.

Trustee: What did you do with these items?

Sophie: My husband gave them to someone without my permission.

Trustee: Who was it?

Sophie: Corrie Delecti.

Trustee: Where are they now?

Sophie:(Fidgeting and awkward silence). Corrie Delecti's apartment in Hard Luck Town.

Trustee: Is that the woman who was recently murdered?

Sophie: Yes. ${ }^{330}$

Trustee: How do you know the cash advances and jewelry are there?

Sophie: My estranged husband told me.

${ }^{330}$ At this point, a judge might have objected on behalf of the debtor and advised her that she had the right to remain silent. Unfortunately for Sophie, trustees have wider latitude of questioning in a creditor's meeting because the court cannot be present. 11 U.S.C. $\$ 341$ (c) (2006). 
Trustee: So, have you been to the apartment and seen the items? Sophie: Well, I've been to the apartment complex, but I did not go into her apartment.

Trustee: When was this?

Sophie: The night that she was killed.

Trustee: So you were in the apartment complex of your husband's mistress on the night that she was murdered, but you didn't go into her apartment? Not even to ask her to give back the jewelry that he had supposedly given to her?

Sophie: No. I was there to see another friend. I did see Ms. Delecti and speak to her, but I did not inquire about the items because I did not know the woman with whom I spoke was Ms. Delecti at that time. I only realized after I saw the news reports of her murder. Ms. Delecti was my friend's neighbor.

Trustee: Can this friend verify that you did not go in to Corrie Delecti's apartment?

Sophie: Well, no. My friend wasn't home that night. I just dropped by and she did not know that I was coming over.

Trustee: So you are asking me to believe that the cash and jewelry were purchased without your knowledge or permission, given to the murdered mistress of your husband, and that you went to her apartment the night of her murder and neither went into her apartment nor asked her about these items. Is that right?

Sophie: Yes. That's the truth. I swear.

Trustee: Have you amended your schedule to reflect these transactions?

Sophie: No.

Trustee: Will you do so?

Sophie: Yes. 


\section{APPENDIX B}

Trustee: Do you solemnly swear or affirm to tell the whole truth? Sophie: I do.

Trustee: Please state your name for the record.

Sophie: My name is Sophie Debtor and I'm from Hard Luck Town.

Trustee: Did you read your voluntary petition and schedules?

Sophie: Yes.

Trustee: Does it include all your property?

Sophie: Yes.

Trustee: Have you listed all of your debts?

Sophie/Counsel: I (my client) respectfully wish(es) to unambiguously invoke my (her) right to the privilege against self-incrimination on the grounds that my (her) response may incriminate me (her). 